\title{
Redescription of Hisonotus notatus Eigenmann \& Eigenmann, 1889 (Loricariidae: Hypoptopomatinae), the type species of the genus, and description of a new species from coastal drainages of southeastern Brazil
}

\author{
Fernanda O. Martins ${ }^{1,2,3}$ and Francisco Langeani ${ }^{1}$
}

Our analyses showed that the type series of Hisonotus notatus, type species of the genus, is mixed, composed by two different species. Based on that, we redescribe H. notatus with the designation of a lectotype, restricting the species to rio São João drainage and other small coastal drainages running to the Baía de Guanabara and to the Baía de Sepetiba in Rio de Janeiro State. We also describe a new species of Hisonotus from drainages of the rio Paraíba do Sul, Lagoa Feia, rio Macaé, and coastal rivers of Espírito Santo State, from rio Itabapoana to rio Doce basin. These two species are sister-taxa and can be distinguished by the number of plates in the mid-dorsal series.

Nossas análises mostraram que a série-tipo de Hisonotus notatus, espécie-tipo do gênero, é mista, composta por duas diferentes espécies. Baseado nisso, nós redescrevemos H. notatus com a designação de um lectótipo, restringindo a espécie à drenagem do rio São João e outras pequenas drenagens que correm para a Baía de Guanabara e para a Baía de Sepetiba no estado do Rio de Janeiro. Também descrevemos uma nova espécie de Hisonotus das drenagens do rio Paraíba do Sul, Lagoa Feia, rio Macaé e rios costeiros do estado do Espírito Santo, do rio Itabapoana à bacia do rio Doce. Essas duas espécies são táxons irmãos e podem ser distinguidas pelo número de placas na série médio-dorsal.

Keywords: Biodiversity, Cascudinhos, Lectotype, Siluriformes, Taxonomy.

\section{Introduction}

Hisonotus is one of the most species-rich genera within the Hypoptopomatinae with 32 valid species, 20 of which described in the last decade (Eschmeyer et al., 2016). The genus was described by Eigenmann \& Eigenmann (1889) to allocate Hisonotus notatus, a species from coastal drainages of southeastern Brazil. The original description was based on 95 specimens from the rio Grande drainage in Santa Cruz farm - Emperor Pedro II's farm, Santa Cruz district, in the urban area of Rio de Janeiro Municipality, Rio de Janeiro State, in addition to a single specimen from rio Paraíba do Sul basin, Juiz de Fora Municipality, Minas Gerais State, collected during the Thayer Expedition. A holotype was not designated, and all the specimens have been considered syntypes of $H$. notatus to date. Also, in that paper the authors referred to some specimens of $H$. notatus among specimens of the type series of Parotocinclus maculicauda (Steindachner, 1877).

Examination of the type series of $H$. notatus and many other specimens from several coastal drainages of Rio de Janeiro and Espírito Santo states revealed that the type series of $H$. notatus is mixed, including specimens of two different species. One of these species occurs both in the coastal drainages of Espírito Santo State and in the rio Paraíba do Sul basin, and the other species is restricted to smaller coastal drainages of Rio de Janeiro State. In fact, recognition of $H$. notatus has not been an easy task mainly because the original description does not provide enough information for an unambiguous identification in the current diverse scenario of Hisonotus. An evidence of this difficulty is that among the four published papers on phylogenetic relationships of the Hypoptopomatinae based on morphological data including $H$. notatus, this identification is confirmed only in Gauger \& Buckup (2005) and Martins et al. (2014). On the other hand, although Schaefer $(1991,1998)$ has recorded the examination of $H$. notatus, the material from rio Ribeira de Iguape quite possibly belongs to Hisonotus leucofrenatus (MirandaRibeiro, 1908). To help clarifying the taxonomic issues mentioned above, in this paper we redescribe $H$. notatus with the designation of a lectotype, and describe a new species, discussing the pattern of geographic distribution of these two species in southeastern Brazil.

\footnotetext{
${ }^{1}$ Universidade Estadual Paulista (UNESP), Instituto de Biociências, Letras e Ciências Exatas, Departamento de Zoologia e Botânica, Laboratório de Ictiologia, rua Cristóvão Colombo, 2265, 15054-000 São José do Rio Preto, SP, Brazil. (FOM) fernanda_martins2@hotmail.com (corresponding author),(FL) langeani@ibilce.unesp.br

${ }^{2}$ Instituto Federal do Paraná (IFPR), Campus Londrina, rua João XXIII, 600, 86060-370 Londrina, PR, Brazil

${ }^{3}$ Museu de Zoologia da Universidade Estadual de Londrina (MZUEL), Rod. Celso Garcia Cid, PR 445, Km 380, Campus Universitário, 86057-970 Londrina, PR, Brazil
} 


\section{Material and Methods}

Measurements were made with digital calipers, pointto-point, on the left side of the specimens to the nearest $0.1 \mathrm{~mm}$, following Martins \& Langeani (2011), with the addition of the following measurements: cleithral width, body width at widest point of pectoral girdle; body depth at dorsal-fin origin; and nasal chamber length, between the anterior and posterior edges of the nostril. Morphometric data were expressed as percents of standard length (SL), except for measurements related to the head, which were given as percents of head length (HL). Osteological nomenclature followed Arratia \& Gayet (1995) and Schaefer (1997). Plate counts followed Schaefer (1997). Procurrent rays and vertebrae were counted only in cleared and stained (c\&s) specimens prepared according to Taylor \& Van Dyke (1985). Vertebrae counts included the five vertebrae from the Weberian apparatus, and the compound caudal centrum was counted as a single element. Dorsal-fin rays count included the spinelet as a spine. The mode of each count is given in parentheses after the respective range. The extent of occurrence of each species was estimated using the software GeoCAT Version BETA (Bachman et al., 2011).

We included the new Hisonotus species described here in the matrix published by Martins et al. (2014), the most recent phylogenetic morphological study for the subfamily. The analysis was performed using the same criteria as the original paper and the 92 character states for the new Hisonotus and H. notatus are presented in Table 1.

Institutional abbreviations are: AMNH (American Museum of Natural History, New York), ANSP (Academy of Natural Sciences of Drexel University, Philadelphia), DZSJRP (Coleção de Peixes do Departamento de Zoologia e Botânica do Instituto de Biociências, Letras e Ciências Exatas, Universidade Estadual Paulista, São José do Rio Preto), MBML (Museu de Biologia Professor Mello Leitão, Santa Teresa), MCP (Museu de Ciências e Tecnologia da Pontifícia Universidade Católica do Rio Grande do Sul, Porto Alegre), MCZ (Museum of Comparative Zoology, Harvard University, Cambridge), MNRJ (Museu Nacional do Rio de Janeiro, Rio de Janeiro), MZUSP (Museu de Zoologia da Universidade de São Paulo, São Paulo).

\section{Results}

\section{Hisonotus thayeri, new species}

urn:1sid:zoobank.org:act:988506F7-FDB5-4752-BDC95FF43DCAD47A

Hisonotus notatus Eigenmann \& Eigenmann, 1889: 41 (original description; partim, specimens from Juiz de Fora captured during the Thayer expedition).

Fig. 1

Holotype. MNRJ 42382, $36.7 \mathrm{~mm}$ SL, female, Brazil, Espírito Santo State, Guarapari, Rio Grande county near the frontier between Guarapari and Anchieta, rio Benevente drainage, 20³7'29”S 40³7’3”W, 26 Jan 1989, J. L. Helmer, C. Zamprogno \& F. Vieira.

Paratypes. All from Brazil. Minas Gerais State: Rio Paraíba do Sul drainage: MNRJ 15937, 1, 24.6 mm SL, Volta Grande, rio Paraíba do Sul, downstream of hydroeletric plant UHE Ilhas dos Pombos, ca. 21 $1^{\circ} 51^{\prime} \mathrm{S}$ $42^{\circ} 36^{\prime}$ W, D. F. Moraes Jr. \& E. P. Caramaschi. MNRJ 15987, 7, 26.1-34.2 mm SL, Volta Grande, rio Paraíba do Sul, downstream of hydroeletric plant UHE Ilhas dos Pombos, ca. $21^{\circ} 51^{\prime}$ S $42^{\circ} 36^{\prime} \mathrm{W}, \mathrm{D}$. F. Moraes Jr. \& E. P. Caramaschi. Rio de Janeiro State: Paraíba do Sul drainage: MNRJ 12837, 2, 20.3-29.9 mm SL (1, 29.9 mm SL), Resende, rio das Pedras, Penedo (Três Cachoeiras),

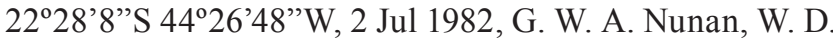
Bandeira \& L. F. M. Silva. MNRJ 14752, 17 (1 c\&s), 27.6$37.8 \mathrm{~mm}$ SL, São Fidélis, affluent to rio Paraíba do Sul, Poço Dantas farm, 25 Oct 1989, D. A. Halboth, N. Viana \& E. P. Caramaschi. MNRJ 15544, 1, $28.0 \mathrm{~mm} \mathrm{SL}$, Teresópolis, rio Paquequer, affluent to rio Preto, rio Piabanha basin, on BR-116 road, $c a .22^{\circ} 28^{\prime} \mathrm{S} 43^{\circ} 0^{\prime} \mathrm{W}, 17$ Feb 1990, E. P. Caramaschi, D. F. Moraes Jr. MNRJ 15913, 18 (1 c\&s), 26.8-39.1 mm SL (10, 27.6-39.1 mm SL), São Fidélis, rio Dois Rios, Poço D'Antas farm, $c a .21^{\circ} 38^{\prime} \mathrm{S}$ 41ํำ'W, 30 Aug 1989, D. A. Halboth, M. Viana \& E. P. Caramaschi. MNRJ 15915, 6, 24.7-36.9 mm SL, São Fidélis, rio Dois Rios, D'Antas farm, ca. $21^{\circ} 38^{\prime}$ 'S 41 ${ }^{\circ} 51^{\prime} \mathrm{W}$, 29 Mar 1989, D. A. Halboth, M. Viana \& E. P. Caramaschi. MNRJ 15916, 9, 28.9-37.3 mm SL, São Fidélis, rio dois

Table 1. Character-state matrix used in the phylogenetic analysis.

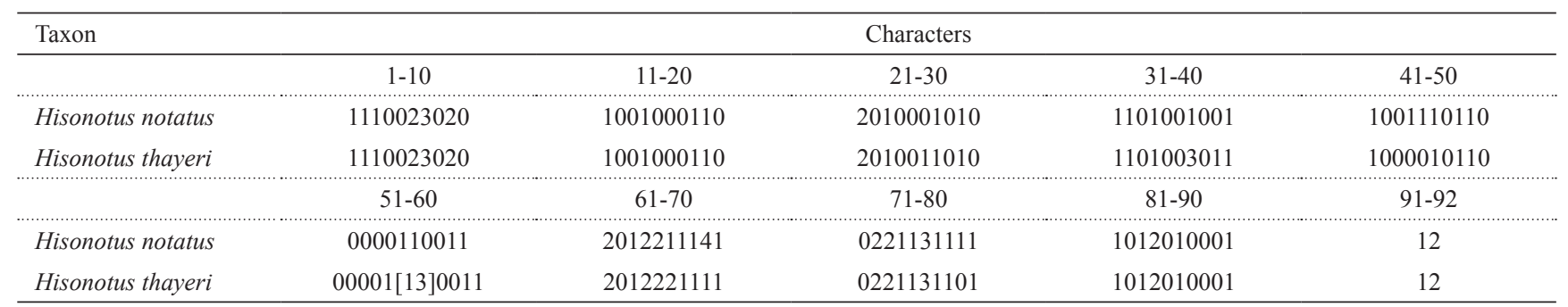


Rios, Poço Dantas farm, ca. $21^{\circ} 38^{\prime} \mathrm{S} 41^{\circ} 51^{\prime} \mathrm{W}, 26$ Apr 1997 , M. Vianna \& J. M. Aranha. MNRJ 15923, 2, 29.83-31.5 $\mathrm{mm}$ SL, Itaperuna, rio Muriaé, near the intersection between BR-356 road and RJ-186 road, ca. 21 ${ }^{\circ} 15^{\prime} \mathrm{S}$ $41^{\circ} 45^{\prime}$ W, 24 Oct 1989, D. F. Moraes, E. P. Caramaschi \& D. A. Halboth. MNRJ 15941, 11, 27.6-41.9 mm SL, São Fidélis, rio Dois Rios, Poço Dantas farm, ca. $21^{\circ} 38^{\prime} \mathrm{S}$ 41ํ5'W, 29 Mar 1989, D. A. Halboth, M. Vianna \& E. P. Caramaschi. MNRJ 15993, 5, 23.7-37.8 mm SL, São Fidélis, rio Dois Rios, Poço Dantas farm, ca. $21^{\circ} 38^{\prime} \mathrm{S}$ 4151'W, 27 Nov 1989, D. F. Moraes \& E. P. Caramaschi. MNRJ 16009, 1, $40.4 \mathrm{~mm}$ SL, Itaperuna, rio São Domingos, affluent to rio Muriaé, $c a$. $21^{\circ} 16^{\prime}$ 'S $41^{\circ} 48^{\prime} \mathrm{W}, 25$ Jul 1989, D. F. Moraes Jr. \& D. A. Halboth. MNRJ 16010, 4, 28.3-37.3 $\mathrm{mm} \mathrm{SL}$, Itaperuna, rio Muriaé, near the intersection between BR-356 road and RJ-186 road, $c a$. $21^{\circ} 15^{\prime}$ 'S 414' W, 24 Jul 1989, D. F. Moraes Jr. \& D. A. Halboth. MNRJ 16056, 3, 30.7-36.3 mm SL, São Fidélis,

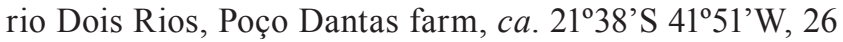
Jul 1989, D. A. Halboth, M. Vianna \& E. P. Caramaschi. MNRJ 16486, 1, 33.3 mm SL, Itaperuna, rio Muriaé, near the intersection between BR-356 road and RJ-186 road, $c a$. $21^{\circ} 15^{\prime}$ S 41 ${ }^{\circ} 45^{\prime} \mathrm{W}, 2$ Nov 1988, D. F. Moraes Jr. \& E. P. Caramaschi. MNRJ 16493, 9 (1 c\&s), 15.9-36.3 mm SL (5, 27.5-36.3 mm SL), Itaocara, rio Negro affluent to rio Dois Rios, near the intersection between BR-116 road and RJ492 road, $c a .21^{\circ} 45^{\prime} \mathrm{S} 42^{\circ} 0^{\prime} \mathrm{W}, 2$ Nov 1988 , E. P. Caramaschi \& D. F. Moraes Jr. MNRJ 16928, 5, 15.6-30.2 mm SL (2, 27.3-30.2 mm SL), Itaperuna, rio Carangola, affluent to rio Muriaé, on BR-356 road, ca. $21^{\circ} 12^{\prime}$ S $41^{\circ} 55^{\prime} \mathrm{W}, 1$ Nov 1988 , D. F. Moraes Jr. \& E. P. Caramaschi. MNRJ 28243, 1, 28.2 $\mathrm{mm}$ SL, Campos dos Goytacazes, rio Muriaé, $c a .21^{\circ} 24^{\prime} \mathrm{S}$ 41ㄴ1'W, 1 Nov 1988, E. P. Caramaschi, D. F. Moraes Jr. et. al. Lagoa Feia drainage: MNRJ 20835, 5, 29.5-42.0 mm SL, Santa Maria Madalena, poço da Mirindiba, rio Sossego, 24 Mar 1998, G. W. A. Nunan, D. F. Moraes \& A. Turler. Rio Macaé drainage: MNRJ 30884, 7, 19.7-35.1 $\mathrm{mm}$ SL, Macaé, rio do Ouro, upstream from cachoeira do Salto, affluent to rio São Pedro, $22^{\circ} 17^{\prime} 15^{\prime \prime} \mathrm{S} 42^{\circ} 0^{\prime} 37^{\prime \prime} \mathrm{W}, 18$ Jan 2003, R. P. Leitão, H. J. Farias \& L. Borely. MNRJ 39303,1 of 13, $35.5 \mathrm{~mm}$ SL, Macaé, rio do Ouro, on Bicuda

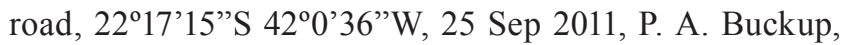
C. Quijada \& J. C. Pascoli. Espírito Santo State: Rio Itapemirim drainage: MBML 1270, 49, 15.8-33.5 mm SL (6, 26.5-33.5 mm SL); DZSJRP 20157, 8 (4 c\&s), 13.4-32.6 mm SL (4, 27.1-32.6 mm SL), Muniz Freire, stream affluent to rio Norte, $20^{\circ} 22^{\prime} 31^{\prime \prime} \mathrm{S} 41^{\circ} 24 ' 41^{\prime \prime} \mathrm{W}, 8$ Oct $2001, \mathrm{R}$. L. Teixeira \& G. I Almeida. MBML 2462, 6, 25.4-37.2 mm SL, Alegre, ribeirão São Bartolomeu downstream from Cachoeira Braúna, 2046’53"S 41²7'12”W, 1 Oct 2009, L. M. Sarmento-Soares, R. F. Martins-Pinheiro, M. R. Britto \& F. M. R. S. Pupo. MBML 2472, 5, 26.0-37.4 mm SL, Cachoeiro de Itapemirim, ribeirão Floresta in Burarama, $20^{\circ} 41^{\prime 2} 20^{\prime \prime S} 41^{\circ} 20^{\prime} 24^{\prime \prime} W, 1$ Oct 2009, L. M. SarmentoSoares, R. F. Martins-Pinheiro, M. R. Britto \& F. M. R. S. Pupo. MBML 3674, 8, 32.3-39.6 mm SL, Atílio Vivácqua, affluent to rio Muqui do Norte on ES-489 road (Joaquim Caiado road) between BR-101 road and Atílio Vivácqua, $20^{\circ} 59^{\prime} 9^{\prime \prime}$ S $41^{\circ} 10^{\prime} 2^{\prime \prime} \mathrm{W}, 21$ Oct 2010, L. M. SarmentoSoares, R. F. Martins-Pinheiro, M. M. C. Roldi \& M. M. Lopes. MBML 3989, 4, 17.9-27.3 mm SL, Muniz Freire, unnamed stream affluent to rio Norte, $20^{\circ} 27^{\prime} 51^{\prime \prime} \mathrm{S}$ $41^{\circ} 24$ '47'W, R. L. Teixeira \& G. I. Almeida. MNRJ 22984, 2, 20.0-29.6 mm SL, Cachoeiro do Itapemirim, córrego Safra on BR-101 road, 20 53 '56"S 41'3'16”'W, 26 Aug 2001, P. A. Buckup, A. T. Aranda, F. A. G. Melo, F. P. Silva, G. R. Moyer \& R. L. Teixeira. MNRJ 25845, 23, 26.0-31.6 mm SL, Muniz Freire, affluent to rio Norte, 11 Sep 2002, R. L. Teixeira. MNRJ 36634, 8, 22.0-37.5 mm SL, Alegre, ribeirão São Bartolomeu, upstream from cachoeira Braúna, 2046'53"S 41²7'12"W, 1 Oct 2009, L. Sarmento-Soares, R. Martins-Pinheiro, M. R. Britto \& F. M. R. S. Pupo. MNRJ 36651, 6, 27.5-39.5 mm SL, Cachoeiro de Itapemirim, ribeirão Floresta in Burarama, 2041'34"S 4120'39'W, 1 Oct 2009, L. Sarmento-Soares, R. Martins-Pinheiro, M. R. Britto \& F. M. R. S. Pupo. MNRJ 38268, 10, 18.2-32.0 mm SL, Muniz Freire, affluent to rio Norte, $20^{\circ} 27^{\prime} 51^{\prime}$ S $41^{\circ} 24 ' 47^{\prime}$ W, 8 Oct 2001, R. L. Teixeira \& G. I. Almeida. Rio Benevente drainage: MBML 479, 37 (2 c\&s), 18.3-37.7 mm SL (7, 29.3-37.7 mm SL); MZUSP 115250, 5, 20.8-38.0 mm SL (3, 32.5-38.0 $\mathrm{mm}$ SL), Alfredo Chaves, rio Joéba, 2048'20"S 40³8'44”W, 2 Mar 2001, R. L. Teixeira \& G. I. Almeida. MBML 1120, 7, 30.3-41.6 mm SL, Alfredo Chaves, córrego Cachoeira Alta in Cachoeira Tororama, $20^{\circ} 38^{\prime} 06^{\prime \prime}$ S 404' $58^{\prime \prime}$ W, 2 Mar 2001, R. L. Teixeira \& G. I. Almeida. MBML 1377, 26, 6.8-31.1 mm SL (7, 26.8-31.1 $\mathrm{mm}$ SL), Alfredo Chaves, córrego Cachoeira Torama, 20³8'6"S 4044'58'W, 29 Jul 2005, R. L. Teixeira. MBML 3157, 20, 21.0-37.7 mm SL, Guarapari, Rio Grande county near the frontier between Guarapari and Anchieta, 20³7'29'S 40³7'3”'W, 10 Mar 1989, J. L. Helmer \& F. Vieira. MBML 3166, 17, 20.7-29.0 mm SL, Guarapari, Rio Grande county near the frontier between Guarapari and Anchieta, 20³7'29'S 40³7'3”'W, 13 May 1989. MBML 3169, 40, 25.8-40.5 mm SL (9, 28.1-40.5 mm SL), collected with holotype. MBML 3196, 21, 17.2-31.6 mm SL, Guarapari, Rio Grande near the frontier between Guarapari and Anchieta, 10 Mar 1989, J. L. Helmer \& F. Vieira. MBML 3223, 6, 25.1-27.8 mm SL, Guarapari, Rio Grande, near to Jaqueira in the frontier between Guarapari and Anchieta, 6 Jan 1989, J. L. Helmer, C. Zamprogno \& F. Vieira. MBML 3259, 35, 24.4-34.8 mm SL, Guarapari, Rio Grande near the frontier between Guarapari and Anchieta, 20³7'29"S 40³7'3"W, 10 Mar 1989, J. H. Helmer \& F. Vieira. MBML 3261, 12, 24.4-35.9 mm SL, Guarapari, Rio Grande near to Jaqueira in the frontier between Guarapari and Anchieta, 6 Jan 1989, J. L. Helmer, C. Zamprogno \& F. Vieira. MBML 3269, 22 (2 c\&s), 13.5$33.3 \mathrm{~mm}$ SL, Guarapari, Rio Grande near the frontier between Guarapari and Anchieta, 13 May 1989,. MBML 3398, 3, 29.6-40.9 mm SL, Alfredo Chaves, rio Caco de 
Pote near Caco de Pote village, 20³6'30"S 4043'16"W, 22 Jun 2010, M. M. Martinelli. MNRJ 38265, 2, Alfredo Chaves, córrego Torotoma, Cachoeira Alta, 20³8'6"S 4044'59"W, 2 Mar 2001, R. L. Teixeira \& G. I. Almeida. MNRJ 39186, 6, 22.6-25.7 mm SL, Guarapari, Rio Grande near the frontier between Guarapari and Anchieta, 20³7'29"S 40³7'3"'W, 10 Mar 1989, J. L. Helmer \& F. Vieira. MNRJ 39200, 5, 17.5-25.4 mm SL, Guarapari, Rio Grande near the frontier between Guarapari and Anchieta, 20³7'29'S 40³7'3”W, 10 Mar 1989, J. L. Helmer \& F. Vieira. MNRJ 39192, 6, 25.1-28.2 mm SL, Guarapari, Rio Grande near the frontier between Guarapari and Anchieta, 26 Jan 1989, J. L. Helmer, C. Zamprogno \& F. Vieira. MNRJ 39191, 6, 14.9-25.3 mm SL, Gurapari, Rio Grande near the frontier between Guarapari and Anchieta, 20³7'29"S 40³7'3"W, 11 Mar 1989, J. L. Helmer \& F. Vieira. Rio Itabapoana drainage: MBML 1766, 3, 26.8$33.0 \mathrm{~mm}$ SL, Mimoso do Sul, ribeirão das Flores, 21 3'51'S 41'21'59'W, 3 Dec 2002, R. L. Teixeira \& G. I. Almeida. MBML 1770, 6, 26.1-39.9 mm SL, Mimoso do Sul, córrego

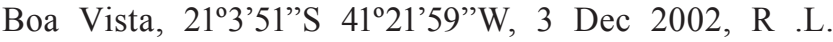
Teixeira \& G. I. Almeida. MBML 3716, 1, 18.3 mm SL, Mimoso do Sul, córrego da Braúna, on ES-319 road (Rubens Rangel road) between Mimoso do Sul and BR-

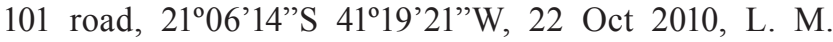
Sarmento-Soares, R. F. Martins-Pinheiro, M. M. C. Roldi, M. M. Lopes \& M. M. Martinelli. MBML 3728, 13 (1 c\&s), 16.2-30.8 mm SL (11, 24.9-30.8 mm SL), Mimoso do Sul, ribeirão das Flores, on José Alves Toledo Road between BR-101 and São José das Torres, 2104'18'S 41'13'44"W, 22 Oct, 2010, L. M. Sarmento-Soares, R. F. Martins-Pinheiro, M. M. C. Roldi, M. M. Lopes \& M. M. Martinelli. MBML 3786, 10, 29.4-41.4 mm SL, Mimoso do Sul, córrego do Farol, affluent to rio Preto, on BR-101 road, 21 7'10'S 4144'34'W, 26 Aug 2001, P. A. Buckup, A. T. Aranda \& F. A. G. Melo. MBML 4080, 1 c\&s, Mimoso do Sul, ribeirão das Flores, on José Alves Toledo Road between BR-101 road and São José das Torres, $21^{\circ} 04^{\prime} 18$ "S 41 ${ }^{\circ} 13$ '44"W, 22 Oct 2010, L. M. SarmentoSoares, R. F. Martins-Pinheiro, M. M .C. Roldi, M. M. Lopes \& M. M. Martinelli. MNRJ 23006, 207, Mimoso do Sul, córrego do Farol, affluent to rio Preto, on BR-101 road, 21\%4'34"S 4113'59'W, 26 Aug 2001, P. A. Buckup, A. T. Aranda, F. A. G. Melo, F. P. Silva, G. R. Moyer \& R. L. Teixeira. Rio Novo drainage: MBML 3362, 11, 11.5$28.1 \mathrm{~mm}$ SL (3, 24.2-28.1 mm SL), Rio Novo do Sul, córrego São Gabriel, affluent to córrego São Vicente de Baixo, 25 Apr 2010, M. M. Martinelli. Rio Doce drainage: MCP 34393, 1, 28.6 mm SL, Itarana, córrego Limoeiro, affluent to rio Santa Joana, 1954'48'S 4050'10"W, 8 Nov 2001, R. L. Teixeira.

Non-types. MCZ 8177, 1, $30.5 \mathrm{~mm} \mathrm{SL}$, paralectotype of Hisonotus notatus, Brazil, Minas Gerais, Juiz de Fora, rio Paraíba do Sul drainage, ca. $21^{\circ} 47^{\prime}$ S 43⒉' $3^{\circ}$, 21 Jun 1865 , L. Agassiz \& J. Whitaker.
Diagnosis. Hisonotus thayeri differs from $H$. aky, $H$. brunneus, $H$. carreiro, $H$. charrua, $H$. heterogaster, $H$. laevior, $H$. megaloplax, $H$. montanus, $H$. nigricauda, $H$. notopagos, $H$. ringueleti, $H$. taimensis, and $H$. vireo by having the anterior portion of snout completely covered by odontodes (Figs. 2b, d) (vs. anterior portion of snout with an odontode-free band between the dorsal and ventral series of odontodes). It distinguishes from $H$. alberti, $H$. depressicauda, $H$. depressinotus, $H$. francirochai, $H$. maculipinnis, $H$. packysarkos, $H$. paulinus, and $H$. prata by having the anterior portion of abdomen covered by large plates arranged in three longitudinal series without naked spaces between them ( $v s$. abdominal plates, when present, not arranged in three longitudinal series, or when arranged with naked spaces between the lateral and median series). It differs from $H$. acuen, $H$. bockmanni, $H$. chromodontus, and $H$. vespuccii by having an ovoid to rectangular spinelet (vs. spinelet $V$-shaped, with lateral projections anteriorly directed). It can be distinguished from $H$. iota and $H$. leucophrys by the absence of well-developed odontodes at the posterior tip of supraoccipital (vs. presence). It differs from $H$. armatus and $H$. hungy by having 28 vertebrae (vs. 25-26 in H. hungy and 29 in H. armatus). It distinguishes from $H$. leucofrenatus by having the clear longitudinal stripe of head ending near the vertical through distal tip of opercle ( $v s$. clear longitudinal stripe longer, bifurcating at the tip of compound pterotic and running parallel to each other; the inferior stripe over the canals of the lateral line, reaching the vertical through the middle of dorsalfin base); bifid neural spine of seventh vertebra present, dorsolaterally projected ( $v s$. bifid neural spine absent); and basipterygia contacting along midline until anterior margin (vs. anterior portion of basipterygia with halves apart from each other). Finally, $H$. thayeri differs from $H$. notatus by having the mid-dorsal series of plates generally continuous, with a total of $15-18$ plates (mode 17 ), rarely with one plate lacking in the middle of the series (Fig. 3) (vs. mid-dorsal series generally interrupted, with 4-13 plates present, and 5-8 lacking plates in the middle of the series).

Description. Morphometric and meristic data in Tables 2 and 3. Dorsal body profile ascending from snout to vertical through posterior edge of eye; slightly convex to dorsal-fin insertion; descending at dorsal-fin base; almost straight to caudal-fin origin, except by small elevation in region of dorsal procurrent rays. Males with dorsal profile generally flattened, sometimes straight from vertical through posterior edge of nostril to caudal-fin origin (as in $H$. notatus, Fig. 4). Ventral body profile almost straight from snout to pelvic-fin insertion; slightly ascending at pelvicfin base; straight to caudal-fin origin, except by slight descent in region of ventral procurrent rays. Greatest body depth at dorsal-fin origin. Greatest body width at opercular opening, gradually tapering towards snout and caudal fin, in dorsal view. Caudal peduncle almost ellipsoid in transverse section. 


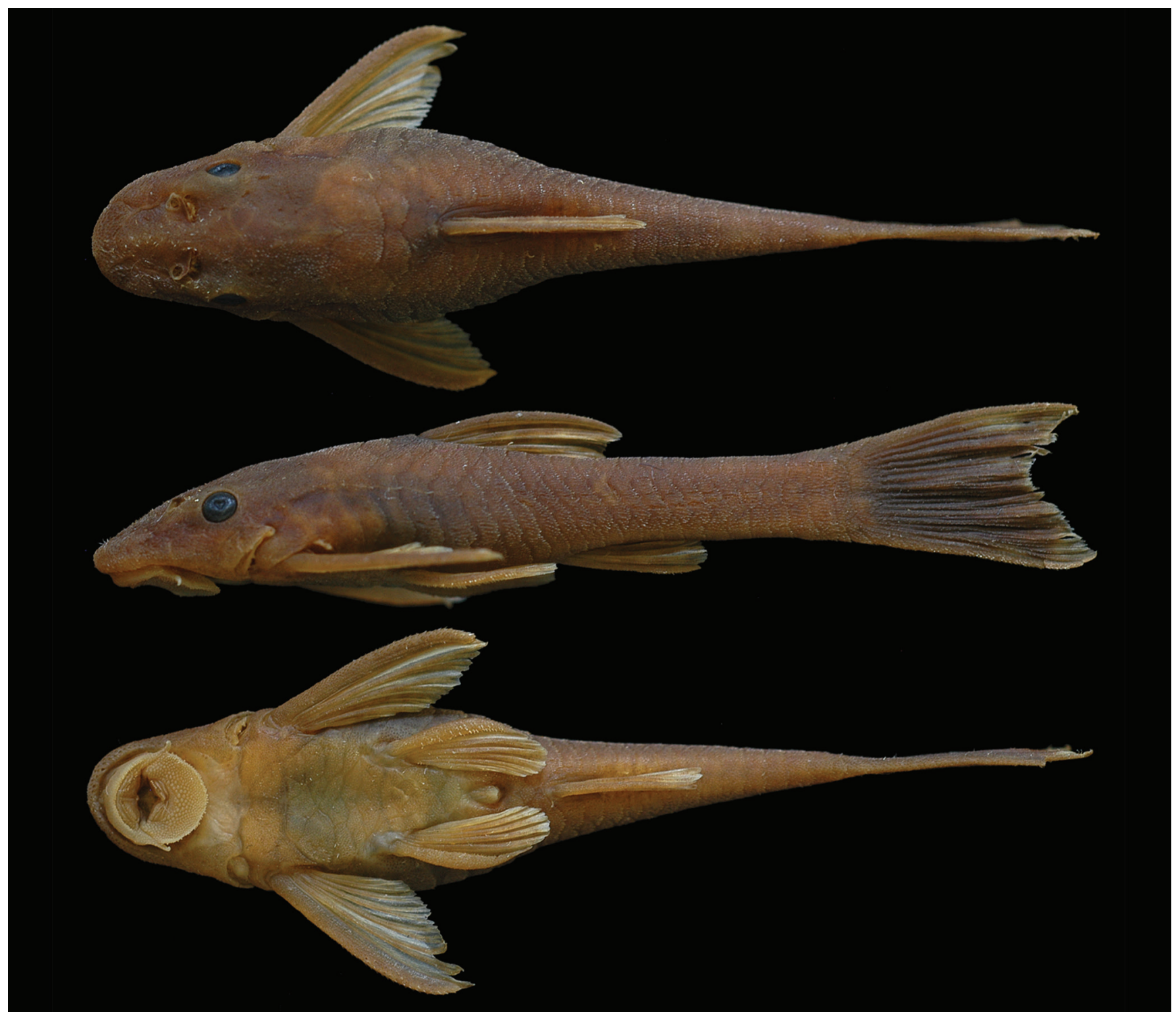

Fig. 1. Hisonotus thayeri, new species, MNRJ 42382, holotype, 36.7 mm SL, female, Brazil, Espírito Santo State, Guarapari Municipality, rio Benevente drainage.

Anterior margin of snout rounded in dorsal view; tip of snout with single large rostral plate, its posterior margin with $U$-or $V$-shaped concavity; well-developed odontodes completely covering ventral and dorsal portions of rostral plate, postrostral plate 1, and lateroventral margin of head (Figs. 2b, d). Remaining odontodes of head and body small, randomly distributed, not forming conspicuous rows, crests or tufts. Eye small, dorsolaterally placed, not visible in ventral view. Iris operculum present. Compound pterotic fenestrae variable in size, small on laterodorsal and large on lateroventral portions; its posterior extension mediumsized and rounded, not surpassing rib of sixth vertebra; infraorbital canal entering infraorbital series via sphenotic. Parieto-supraoccipital not forming part of dorsal wall of swimbladder capsule.

Body entirely covered by dermal plates, except on ventral part of head, region overlying opening of swimbladder capsule, pelvic-fin origin, and urogenital pore. Abdomen completely covered by large plates; anterior plates arranged in three longitudinal rows, sometimes unaligned, the lateral rows with 1-5(3) plates; posterior plates, between pelvic fins, randomly distributed.

Lips oval, papillose; lower lip fringy, larger than upper, falling short of pectoral girdle; papillae gradually smaller towards lip edge. Maxillary barbel reduced, free from oral disk. Teeth slender and bifid; median cusp larger and rounded, lateral smaller and pointed. Premaxillary and dentary accessory teeth absent, even in smallest examined specimen (13.3 mm SL).

Dorsal fin originating approximately at vertical through end of pelvic-fin base; tip of adpressed rays surpassing vertical line at end of anal-fin base. Spinelet small, ovoid, inserted in notch in nuchal plate; locking mechanism non-functional. Nuchal plate exposed area rectangular to 


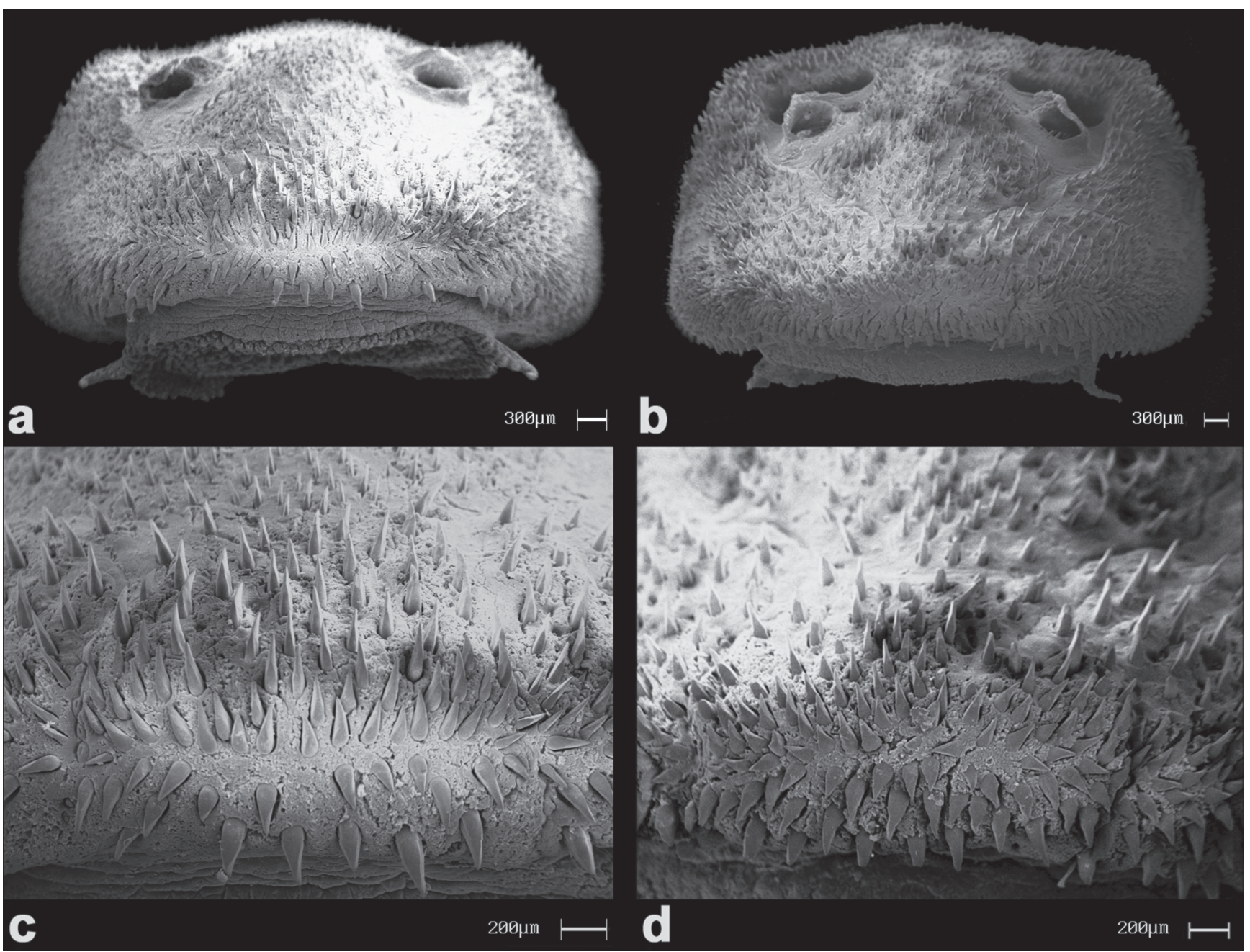

Fig. 2. Scanning electron micrographs of tip of snout of Hisonotus notatus, DZSJRP 13852, $34.6 \mathrm{~mm}$ SL (a, c) and Hisonotus thayeri, MNRJ 14752, $38.4 \mathrm{~mm}$ SL, paratype (b, d).
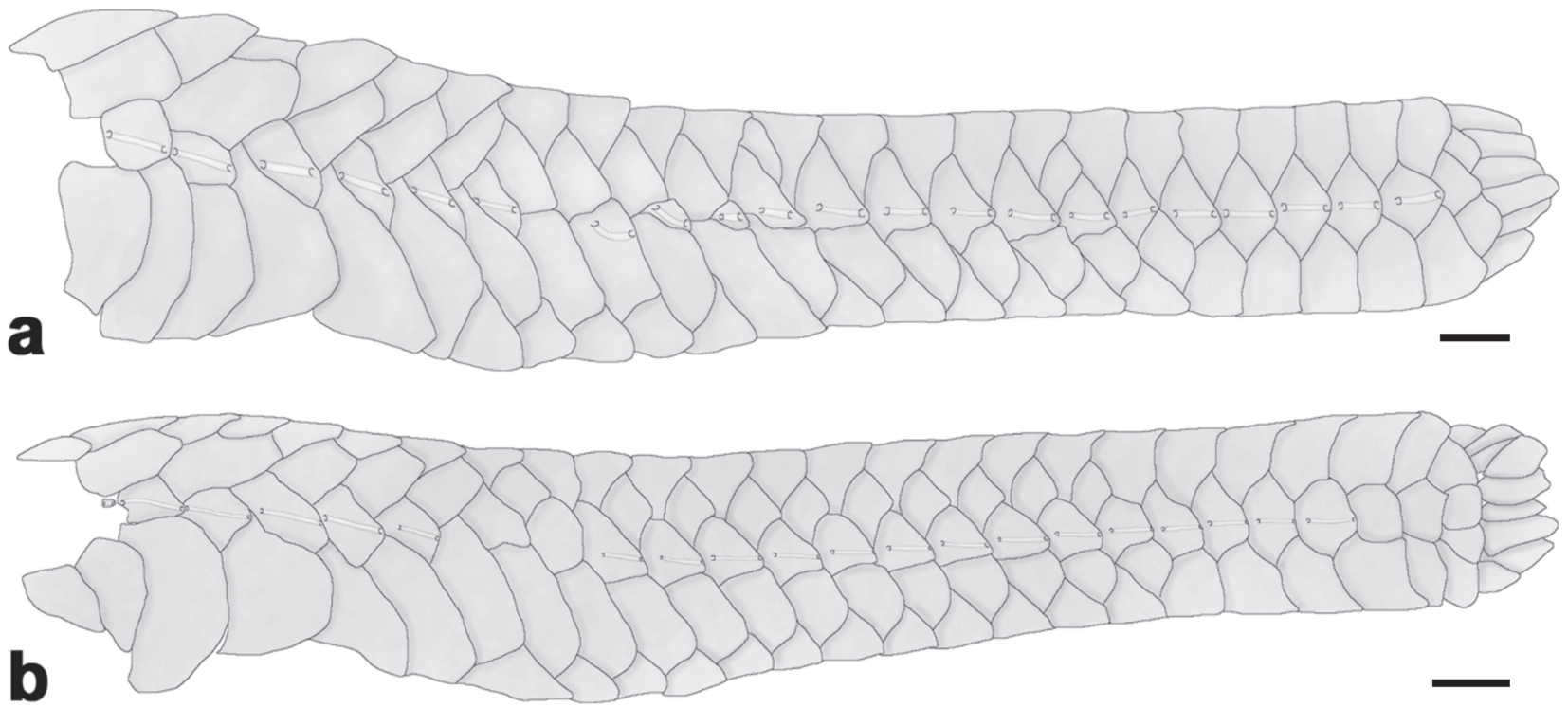

Fig. 3. Lateral plates of trunk of Hisonotus notatus, DZSJRP 13852, $31.5 \mathrm{~mm}$ SL, male (a) and Hisonotus thayeri, DZSJRP 20157, paratype, $32.4 \mathrm{~mm} \mathrm{SL}$, female (b), left side. Scale bars $=1 \mathrm{~mm}$. 
pentagonal. Anterior portion of compound supraneural first dorsal-fin proximal radial contacting neural spine of seventh vertebra. Pectoral fin originating immediately behind opercular opening; tip of adpressed rays almost reaching vertical through urogenital opening; well-developed odontodes on unbranched ray, gradually enlarged towards tip. Cleithrum and coracoid almost totally exposed, with many odontodes, except for arrector fossa region covered by skin only. Arrector fossa almost completely enclosed by ventral lamina of coracoid and cleithrum, opening restricted to small anterior area near midline. Pectoral axillary slit present in juveniles and adults, large, about 1.3-1.7 times in orbital diameter, at angle of $45^{\circ}$ with body axis. Pelvicfin unbranched ray shorter than branched ones. Anal-fin first proximal radial contacting haemal spine of 12th or 13th vertebrae. Caudal fin concave, lower lobe slightly longer than upper. Adipose fin and azygous plates absent.

Five lateral series of plates (Fig. 3b). Dorsal series complete from posterior edge of supraoccipital to caudalpeduncle end. Mid-dorsal series long, rarely with missing intermediate plates. Median series from compound pterotic to caudal-fin base; in general, 1-3 plates lacking and/or 1-2 non-perforated plates in middle portion of series, near vertical through dorsal-fin base, and 1-4 non-perforated plates at end of series; first plate, sometimes also second, restricted to sensorial canal, occasionally fused to compound pterotic. Mid-ventral series long, from lateral process of cleithrum to vertical through tip of adpressed anal fin. Ventral series from near middle or end of pelvic-fin length to caudal-peduncle end.

Table 2. Morphometric data for Hisonotus thayeri, holotype $(\mathrm{H})$ and 105 paratypes; range includes holotype. SD = Standard deviation.

\begin{tabular}{|c|c|c|c|c|c|}
\hline Character & $\mathrm{H}$ & Minimum & Maximum & Mean & $\mathrm{SD}$ \\
\hline \multirow[t]{2}{*}{ Standard length (mm) } & 36.7 & 24.3 & 42.0 & & \\
\hline & \multicolumn{5}{|c|}{ Percents of standard length } \\
\hline Predorsal length & 45.6 & 43.9 & 49.0 & 46.7 & 1.1 \\
\hline Preanal length & 61.7 & 59.2 & 65.8 & 62.8 & 1.4 \\
\hline Prepectoral length & 25.5 & 24.9 & 30.8 & 27.0 & 1.1 \\
\hline Prepelvic length & 39.5 & 38.5 & 44.7 & 41.7 & 1.4 \\
\hline Postanal length & 33.6 & 27.8 & 42.1 & 32.2 & 1.7 \\
\hline Thoracic length & 16.0 & 13.8 & 19.3 & 16.8 & 1.1 \\
\hline Abdominal length & 20.6 & 18.4 & 24.1 & 21.4 & 1.1 \\
\hline Caudal-peduncle depth & 10.8 & 9.5 & 12.2 & 10.8 & 0.5 \\
\hline Head length & 34.2 & 31.5 & 38.1 & 35.1 & 1.2 \\
\hline Cleithral width & 24.0 & 21.1 & 25.9 & 23.2 & 1.0 \\
\hline Base of dorsal fin length & 12.1 & 10.9 & 15.4 & 12.6 & 0.8 \\
\hline Dorsal-fin unbranched ray length & 27.6 & 21.4 & 28.9 & 25.2 & 1.4 \\
\hline Pectoral-fin unbranched ray length & 30.4 & 23.3 & 32.1 & 28.4 & 1.4 \\
\hline Pelvic-fin unbranched ray length & 18.8 & 14.2 & 23.6 & 19.1 & 2.0 \\
\hline Females & - & 14.2 & 19.3 & 17.5 & 1.0 \\
\hline Males & - & 18.4 & 23.6 & 20.8 & 1.3 \\
\hline Dorsal to anal fin length & 25.2 & 20.1 & 26.4 & 23.4 & 1.1 \\
\hline Snout-opercle length & 25.3 & 24.8 & 28.8 & 26.7 & 0.9 \\
\hline \multirow[t]{2}{*}{ Body depth } & 18.8 & 12.4 & 23.5 & 17.5 & 1.5 \\
\hline & \multicolumn{5}{|c|}{ Percents of head length } \\
\hline Head width & 67.4 & 57.4 & 71.4 & 63.7 & 2.8 \\
\hline Head depth & 49.4 & 37.2 & 52.5 & 45.0 & 2.9 \\
\hline Snout length & 50.2 & 48.0 & 57.1 & 51.6 & 1.6 \\
\hline Orbital diameter & 14.7 & 12.8 & 18.9 & 15.7 & 1.2 \\
\hline Interorbital length & 43.1 & 35.0 & 46.8 & 41.2 & 2.1 \\
\hline Maxillary barbel length & 4.4 & 1.7 & 8.6 & 5.6 & 1.6 \\
\hline Prenasal length & 30.1 & 26.7 & 37.6 & 31.4 & 2.0 \\
\hline Internasal length & 9.6 & 7.1 & 15.0 & 11.1 & 1.8 \\
\hline Nasal chamber width & 11.2 & 9.3 & 16.4 & 12.4 & 1.9 \\
\hline Females & - & 9.3 & 12.6 & 10.8 & 0.7 \\
\hline Males & - & 12.1 & 16.4 & 14.1 & 1.1 \\
\hline Nasal chamber length & 14.5 & 11.3 & 20.9 & 16.0 & 2.4 \\
\hline Females & - & 11.3 & 17.4 & 14.2 & 1.5 \\
\hline Males & - & 15.1 & 20.9 & 17.9 & 1.5 \\
\hline Suborbital depth & 19.9 & 14.3 & 23.0 & 18.6 & 1.5 \\
\hline
\end{tabular}


Table 3. Frequency distribution of meristic data for Hisonotus thayeri, holotype and 112 paratypes. Plates (in both sides for paratypes) and procurrent rays were counted only in c\&s specimens and holotype, and vertebrae only in c\&s specimens. Holotype values are marked with an asterisk.

\begin{tabular}{|c|c|c|c|}
\hline Character & Frequency distribution & Range & Mode \\
\hline Dorsal plates & $23(5)^{*}, 24(5), 25(5)$ & $23-25$ & $24 / 25$ \\
\hline Mid-dorsal plates & $15(3)^{*}, 16(2), 17(8), 18(2)$ & $15-18$ & 17 \\
\hline Total median plates & $23(2), 24(4), 25(6)^{*}, 26(3)$ & $23-26$ & 25 \\
\hline unperforated near caudal- peduncle end & $1(1), 2(5), 3(6), 4(2), 5(1)^{*}$ & $1-4$ & 3 \\
\hline Mid-ventral plates & $17(1), 18(3)^{*}, 19(7), 20(3), 21(1)$ & $17-21$ & 19 \\
\hline Ventral plates & $17(1), 18(6), 19(6) *, 20(1), 21(1)$ & $17-21$ & 18 \\
\hline Lateral abdominal plates & $1(3), 2(8), 3(44), 4(36)^{*}, 5(15)$ & $1-5$ & 3 \\
\hline Premaxillary teeth & $17(2), 18(4), 19(10), 20(10), 21(13), 22(17) *, 23(18), 24(7), 25(14), 26(6), 27(3), 28(1), 29(1)$ & $17-29$ & 23 \\
\hline Dentary teeth & 15(1), 16(3), 17(11), 18(8), 19(17), 20(13), 21(13), 22(14)*, 23(14), 24(4), 25(1), 26(1) & $15-26$ & 19 \\
\hline Dorsal-fin branched rays & $6(6), 7(100)^{*}$ & $6-7$ & 7 \\
\hline Pectoral-fin branched rays & $5(6), 6(100)^{*}$ & $5-6$ & 6 \\
\hline Pelvic-fin unbranched rays & $5(105)^{*}, 6(1)$ & $5-6$ & 5 \\
\hline Anal-fin unbranched rays & $4(1), 5(105) *$ & $4-5$ & 5 \\
\hline Caudal-fin unbranched rays & 13(4), 14(101)*, 15(1) & $13-15$ & 14 \\
\hline Dorsal procurrent rays & $3(1), 4(4)^{*}, 5(3)$ & $3-5$ & $4 / 5$ \\
\hline Ventral procurrent rays & $3(1), 4(2), 5(5)^{*}$ & $3-5$ & 5 \\
\hline Vertebrae & $27(1), 28(6)$ & $27-28$ & 28 \\
\hline
\end{tabular}

Color in alcohol. Dorsal profile medium brown; dorsal area of head dark brown from tip of snout to median portion of supraoccipital. Three dorsal inconspicuous saddles: first at dorsal-fin base; second at end of dorsalfin length; third at end of caudal peduncle. Clear stripe extending from tip of snout to near vertical through distal tip of opercle, passing by dorsal margin of postrostral plates 1 and 2, external edge of nostril, limits between prefrontal and infraobitals 2 and 3, and dorsal margin of orbit. Lateral profile of body homogeneously medium brown, except for yellowish lateroventral portion of head and lateral process of cleithrum, sometimes with spots forming vermiculated pattern. Ventral portion of body yellowish.

Membranes of dorsal, anal, pectoral, and pelvic fins hyaline, pigmented areas of rays arranged in interspersed bars forming transversal bands. Caudal fin densely pigmented, except for slender unpigmented edge and hyaline areas in both lobes: superior lobe with oblique blotch from posteromedial portion of unbranched ray to distal portion of median rays, and other at superior tip of lobe, these two areas separated by dark inclined line; inferior lobe with small posteromedial area restricted to unbranched ray and last branched ray, and another at inferior tip of lobe.

Sexual dimorphism. Males in general smaller and with dorsal profile more depressed than females (as in H. notatus, Fig. 4), the latter feature being rare among Hypoptopomatinae species, and reported for the first time here. Males have conspicuous urogenital papilla immediately posterior to anus, expanded flap of skin on dorsal surface of the first pelvic-fin ray, and tip of adpressed pelvic fin generally reaching anal-fin origin. Nasal chamber of males generally enlarged, its width 12.1$16.4 \%$ in HL (mean 14.1\%) [vs. 9.3-12.6\% (mean 10.8\%) in females], and its length $15.1-20.9 \%$ in HL (mean $17.9 \%$ ) [vs. 11.3-17.4\% (mean 14.2\%) in females].

Distribution. The species occurs in the coastal basins of rio Paraíba do Sul, Lagoa Feia, rio Macaé, rio Itabapoana, rio Itapemirim, rio Novo, rio Benevente, and rio Doce, in Minas Gerais, Rio de Janeiro and Espírito Santo states (Fig. 5).

Etymology. The specific epithet thayeri is named after the Thayer Expedition, realized in the middle of the 19th century and considered one of the most important journeys performed in Brazil, during which the species was sampled for the first time. A genitive.

Conservation status. Hisonotus thayeri is a common and abundant species in the sampling sites, widely distributed in the coastal basins of rio Paraíba do Sul, Lagoa Feia, rio Macaé, rio Itabapoana, rio Itapemirim, rio Novo, rio Benevente, and rio Doce, with extent of occurrence (EOO) of approximately $42,105 \mathrm{~km}^{2}$. As today we did not recognize any threats that may endanger it and the species population is apparently stable, according to the International Union for Conservation of Nature (IUCN) categories and criteria (IUCN Standards and Petitions Subcommittee, 2014), Hisonotus thayeri can be classified as Least Concern (LC). 


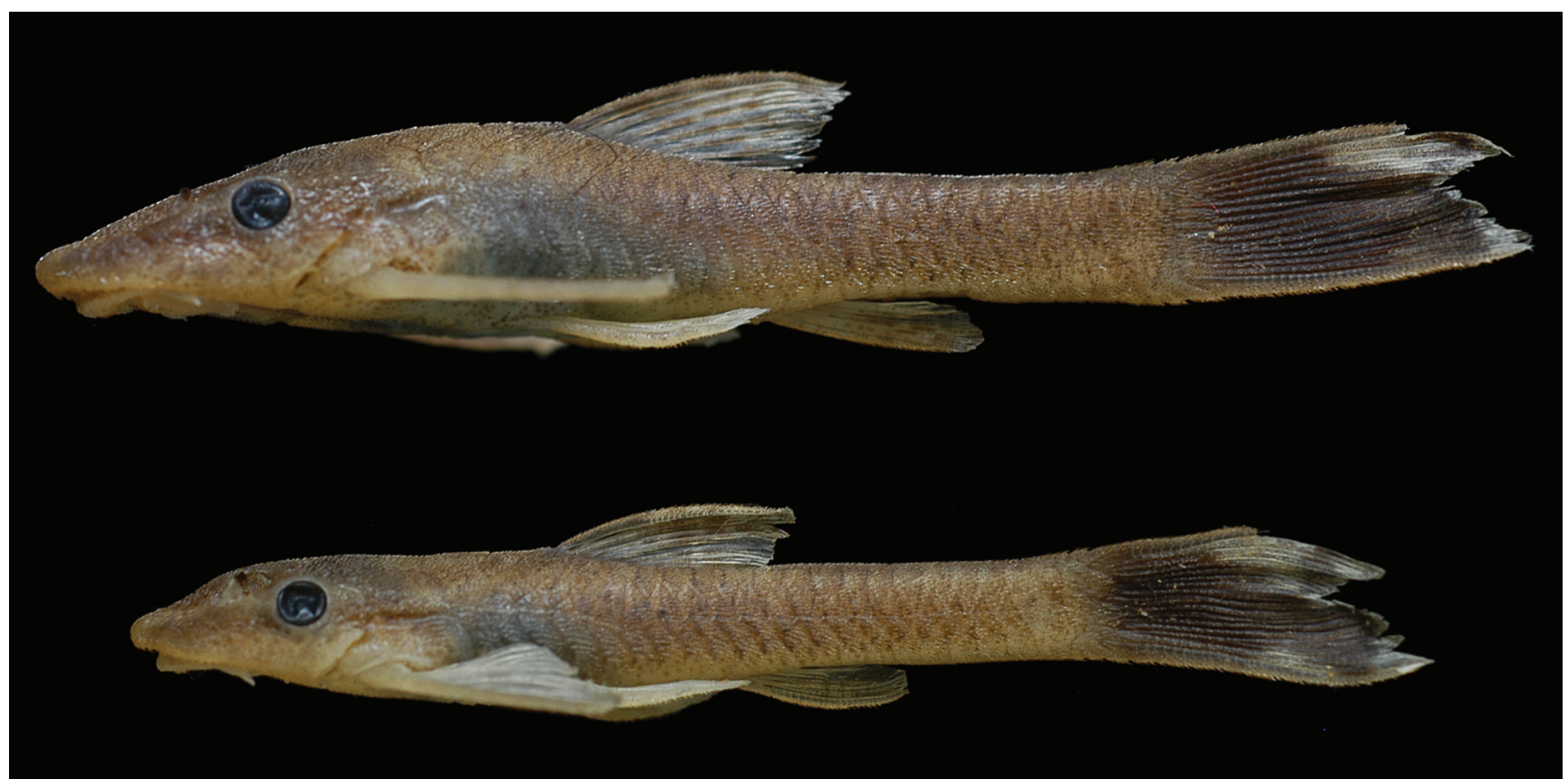

Fig. 4. Sexual dimorphism in body depth in Hisonotus notatus, MNRJ 38147, female, $37.2 \mathrm{~mm}$ SL (above), and male 32.3 mm SL (below).

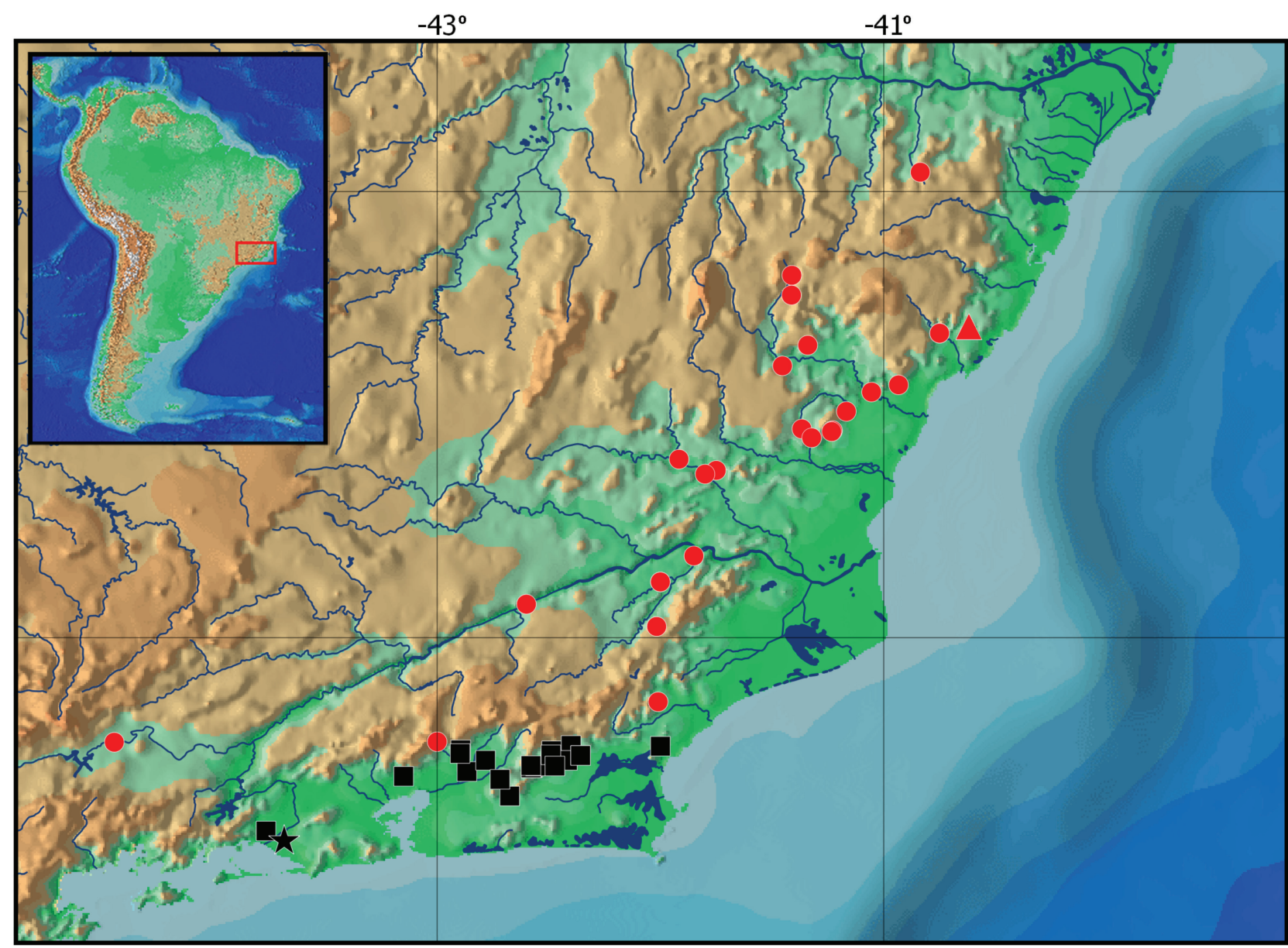

Fig. 5. Geographic distribution of Hisonotus notatus (black squares, and star for type locality) and Hisonotus thayeri (red dots, and triangle for type locality) in southeastern Brazilian costal drainages. Symbols can represent more than one sampling locality. 


\section{Hisonotus notatus Eigenmann \& Eigenmann, 1889}

Figs. 6-7

Otocinclus maculicauda Steindachner, 1877: 222 (partim, specimens without adipose fin).

Hisonotus notatus Eigenmann \& Eigenmann, 1889: 41 (original description; partim, specimens from Santa Cruz). -Eigenmann \& Eigenmann, 1890: 391 (catalogue; cited as minutus (lapsus) referring to notatus). -Eschmeyer, 1998: 1198 (catalogue) -Schaefer, 2003: 323 (catalogue). -Gauger \& Buckup, 2005 (phylogenetic relationships). -Ferraris, 2007: 248 (catalogue). -Reis \& Carvalho, 2007: 84 (catalogue). -Martins et al., 2014: 864 (phylogenetic relationships).

Otocinclus notatus. -Regan, 1904: 266 (identification key), 268 (catalogue). -Miranda-Ribeiro, 1911: 91 (identification key); 93 (catalogue; Rio Grande do Sul State erroneously cited as type-locality). -Fowler, 1954: 130 (catalogue).

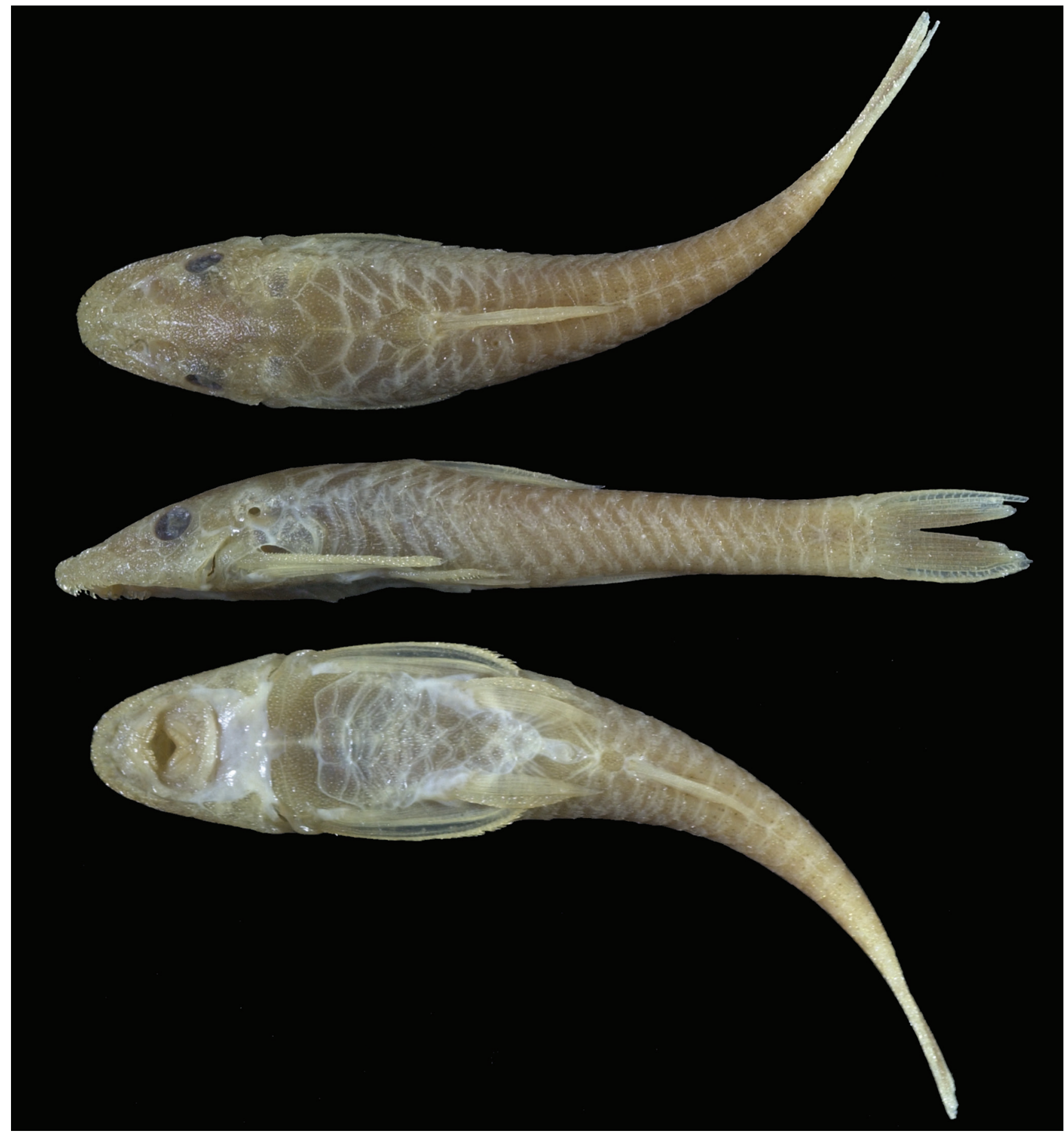

Fig. 6. Hisonotus notatus, MCZ 7764, paralectotype, $29.2 \mathrm{~mm} \mathrm{SL}$, female, Brazil, Rio de Janeiro, Santa Cruz district. 


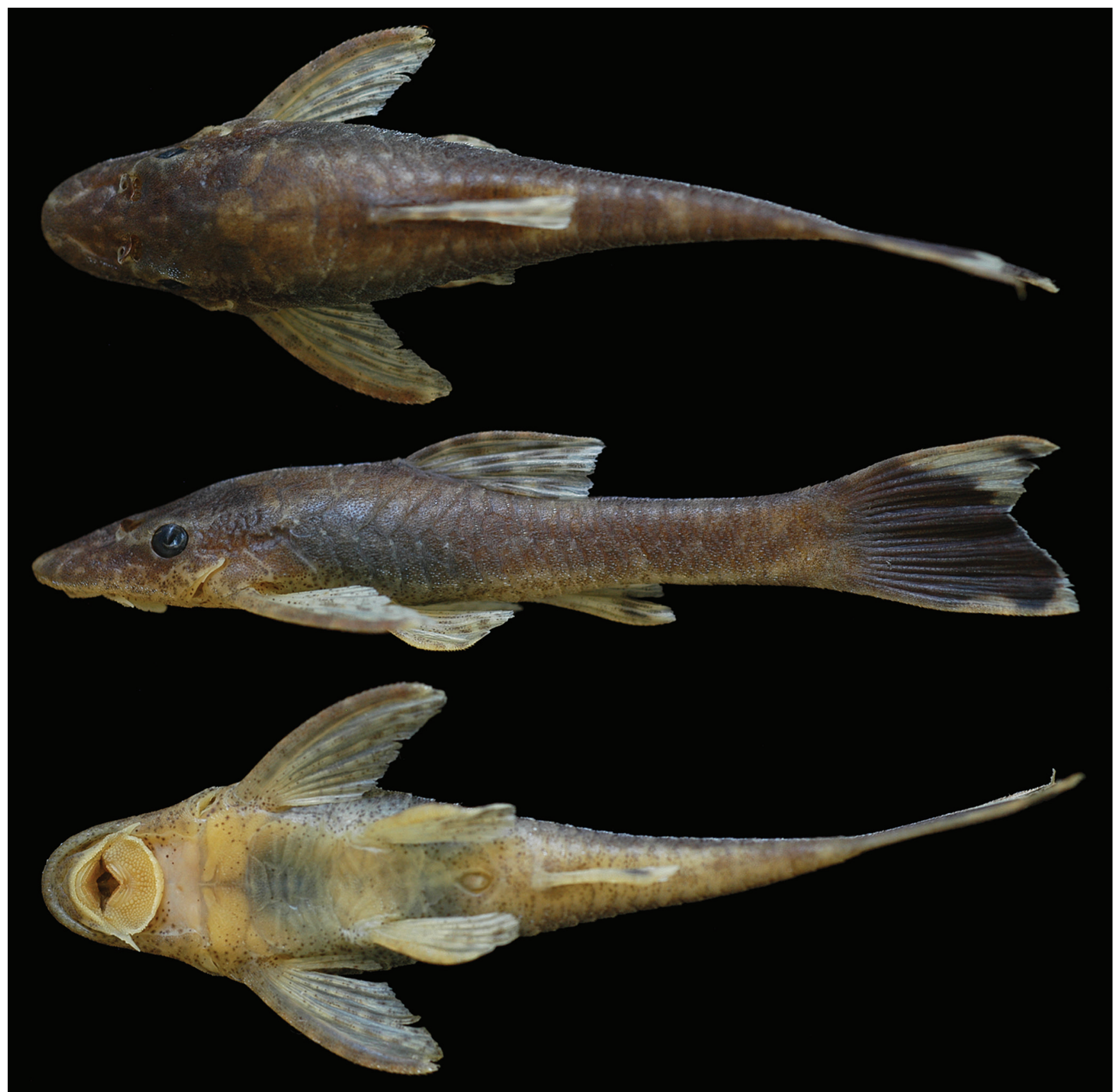

Fig. 7. Hisonotus notatus, DZSJRP 13874, non-type, $43.5 \mathrm{~mm}$ SL, female, Brazil, Rio de Janeiro, Silva Jardim Municipality, rio São João drainage.

Diagnosis. Hisonotus notatus differs from $H$. aky, $H$. brunneus, $H$. carreiro, $H$. charrua, $H$. heterogaster, $H$. laevior, $H$. megaloplax, $H$. montanus, $H$. nigricauda, $H$. notopagos, $H$. ringueleti, $H$. taimensis, and $H$. vireo by having the anterior portion of snout completely covered by odontodes (Fig. 2) (vs. anterior portion of snout with an odontode-free band between the dorsal and ventral series of odontodes). It distinguishes from $H$. alberti, $H$. depressicauda, $H$. depressinotus, $H$. francirochai, $H$. maculipinnis, $H$. packysarkos, $H$. paulinus, and $H$. prata by having the anterior portion of abdomen covered by large plates arranged in three longitudinal series without naked spaces between them (vs. abdominal plates, when present, not arranged in three longitudinal series, or when arranged with naked spaces between the lateral and median series). It differs from $H$. acuen, $H$. bockmanni, $H$. chromodontus, and $H$. vespuccii by having an ovoid to rectangular spinelet (vs. spinelet $V$-shaped, with lateral projections anteriorly directed). It can be distinguished from $H$. iota and $H$. leucophrys by the absence of well-developed odontodes at posterior tip of supraoccipital (vs. presence). It differs from $H$. armatus and $H$. hungy by having 28 vertebrae (vs. 25-26 in $H$. hungy and 29 in H. armatus). It distinguishes from $H$. leucofrenatus by having the clear longitudinal stripe of 
head ending near the vertical through distal tip of opercle (vs. clear longitudinal stripe longer, bifurcating at the tip of compound pterotic and running parallel to each other; the inferior stripe over the canals of the lateral line, reaching the vertical through the middle of dorsal-fin base); bifid neural spine of seventh vertebra present, dorsolaterally projected ( $v s$. bifid neural spine absent); and basipterygia contacting along midline until anterior margin (vs. anterior portion of basipterygia with halves slightly apart from each other). Finally, $H$. notatus differs from $H$. thayeri by having the mid-dorsal series of plates generally interrupted, with a total of 4-13 plates (mode 5), 5-8 lacking plates in the middle of the series (Fig. 3) (vs. mid-dorsal series of plates generally continuous, with $15-18$ plates (mode 17), rarely one plate lacking in the middle of the series).
Description. Morphometric and meristic data in Tables 4-7. Dorsal body profile ascending from snout to vertical through posterior edge of eye; slightly convex to dorsalfin insertion; descending at dorsal-fin base; almost straight to caudal-fin origin, except by small elevation in region of dorsal procurrent rays. Males with dorsal profile generally flattened, sometimes straight from vertical through posterior edge of nostril to caudal-fin origin (Fig. 4). Ventral body profile almost straight from snout to pelvic-fin insertion; slightly ascending at pelvic-fin base; straight to caudal-fin origin, except by slight descent in region of ventral procurrent rays. Greatest body depth at dorsal-fin origin. Greatest body width at opercular opening, gradually tapering towards snout and caudal fin. Caudal peduncle almost ellipsoid in transverse section.

Table 4. Morphometric data for Hisonotus notatus, lectotype (L) and 19 paralectotypes; range includes lectotype. SD = Standard deviation.

\begin{tabular}{|c|c|c|c|c|c|}
\hline Character & $\mathrm{L}$ & Minimum & Maximum & Mean & $\mathrm{SD}$ \\
\hline \multirow[t]{2}{*}{ Standard length $(\mathrm{mm})$} & 31.3 & 24.3 & 32.2 & - & - \\
\hline & \multicolumn{5}{|c|}{ Percents of standard length } \\
\hline Predorsal length & 47.6 & 45.4 & 49.8 & 48.3 & 1.2 \\
\hline Preanal length & 64.2 & 61.2 & 66.6 & 63.9 & 1.5 \\
\hline Prepectoral length & 27.2 & 24.7 & 29.0 & 27.4 & 1.0 \\
\hline Prepelvic length & 44.1 & 39.6 & 44.9 & 42.5 & 1.6 \\
\hline Postanal length & 33.9 & 30.3 & 34.9 & 32.6 & 1.0 \\
\hline Thoracic length & 19.2 & 14.7 & 20.1 & 17.1 & 1.6 \\
\hline Abdominal length & 18.8 & 18.4 & 22.8 & 20.6 & 1.2 \\
\hline Caudal-peduncle depth & 9.6 & 8.8 & 10.2 & 9.5 & 0.4 \\
\hline Head length & 34.5 & 34.4 & 37.5 & 35.6 & 0.9 \\
\hline Cleithral width & 22.0 & 20.7 & 22.7 & 21.7 & 0.6 \\
\hline Base of dorsal fin length & 12.5 & 8.4 & 13.7 & 11.1 & 1.1 \\
\hline Dorsal-fin unbranched ray length & 21.7 & 21.5 & 25.2 & 23.2 & 1.2 \\
\hline Pectoral-fin unbranched ray length & 24.0 & 23.5 & 27.7 & 25.6 & 1.3 \\
\hline Pelvic-fin unbranched ray length & 16.9 & 14.0 & 21.2 & 17.1 & 1.5 \\
\hline Dorsal to anal fin length & 21.4 & 21.4 & 24.4 & 22.5 & 0.7 \\
\hline Snout-opercle length & 27.8 & 25.8 & 28.3 & 27.1 & 0.6 \\
\hline \multirow[t]{2}{*}{ Body depth } & 15.0 & 13.0 & 16.0 & 14.6 & 0.8 \\
\hline & \multicolumn{5}{|c|}{ Percents of head length } \\
\hline Head width & 61.1 & 54.0 & 61.1 & 57.2 & 2.3 \\
\hline Head depth & 42.6 & 38.9 & 43.8 & 41.1 & 1.3 \\
\hline Snout length & 48.2 & 46.6 & 50.9 & 49.0 & 1.2 \\
\hline Orbital diameter & 16.7 & 15.1 & 17.5 & 16.3 & 0.7 \\
\hline Interorbital length & 38.9 & 34.3 & 39.3 & 37.1 & 1.5 \\
\hline Maxillary barbel length & 2.8 & 2.8 & 8.6 & 5.9 & 1.5 \\
\hline Prenasal length & 32.4 & 26.9 & 33.8 & 30.4 & 1.7 \\
\hline Internasal length & 13.0 & 6.0 & 15.8 & 11.5 & 2.0 \\
\hline Nasal chamber width & 10.2 & 7.2 & 16.7 & 11.1 & 2.1 \\
\hline Females & - & 7.2 & 11.8 & 10.0 & 1.1 \\
\hline Males & - & 12.5 & 16.7 & 13.7 & 1.5 \\
\hline Nasal chamber length & 13.0 & 10.7 & 18.6 & 14.4 & 2.5 \\
\hline Suborbital depth & 16.7 & 14.6 & 17.2 & 15.9 & 0.8 \\
\hline
\end{tabular}


Table 5. Frequency distribution of meristic data for Hisonotus notatus, lectotype and 19 paralectotypes. Lectotype values are marked with an asterisk.

\begin{tabular}{lccc}
\hline Character & Frequency distribution & Range & Mode \\
\hline Dorsal plates & $22(3)^{*}, 23(5), 24(11), 25(1)$ & $22-25$ & 24 \\
Mid-dorsal plates & $3(1), 4(3), 5(8)^{*}, 6(4), 7(1), 9(2), 10(1)$ & 5 & $22-25$ \\
Median plates & $22(2), 23(6)^{*}, 24(5), 25(7)$ & $17-21$ & $17-21$ \\
Mid-ventral plates & $17(1), 18(3), 19(12)^{*}, 20(3), 21(1)$ & $3-7$ & 19 \\
Ventral plates & $17(1), 18(4), 19(10), 20(4)^{*}, 21(1)$ & $14-20$ & $5-16$ \\
Lateral abdominal plates & $3(2), 4(5), 5(6), 6(6), 7(1)^{*}$ & $6-7$ & $18 / 20$ \\
Premaxillary teeth & $15(1), 17(4), 18(5)^{*}, 19(2), 20(5)$ & 16 & 7 \\
Dentary teeth & $9(1)^{*}, 12(1), 13(1), 14(3), 15(3), 16(4)$ & - & 6 \\
Dorsal-fin branched rays & $7(20)^{*}$ & - & 5 \\
Pectoral-fin branched rays & $6(20)^{*}$ & $5(20)^{*}$ & $13-14$ \\
Pelvic-fin unbranched rays & $5(20)^{*}$ & $4-6$ \\
Anal-fin unbranched rays & $13(1), 14(19)^{*}$ & $3-5$ \\
Caudal-fin unbranched rays & $4(8)^{*}, 5(11), 6(1)$ & 5 \\
Dorsal procurrent rays & $3(4), 4(13)^{*}, 5(3)$ & 5 \\
Ventral procurrent rays & & 4 \\
\hline
\end{tabular}

Table 6. Morphometric data for Hisonotus notatus non-types ( $\mathrm{n}=39)$. SD = Standard deviation.

\begin{tabular}{|c|c|c|c|c|}
\hline Character & Minimum & Maximum & Mean & SD \\
\hline \multirow[t]{2}{*}{ Standard length $(\mathrm{mm})$} & 27.3 & 45.2 & - & - \\
\hline & \multicolumn{3}{|c|}{ Percents of standard length } & \\
\hline Predorsal length & 44.1 & 49.2 & 46.7 & 1.3 \\
\hline Preanal length & 60.5 & 65.6 & 62.9 & 1.2 \\
\hline Prepectoral length & 24.0 & 29.2 & 26.4 & 1.2 \\
\hline Prepelvic length & 39.3 & 44.8 & 42.2 & 1.3 \\
\hline Postanal length & 30.3 & 35.1 & 32.7 & 1.2 \\
\hline Thoracic length & 15.0 & 20.4 & 17.9 & 1.2 \\
\hline Abdominal length & 18.9 & 23.3 & 21.1 & 1.0 \\
\hline Caudal-peduncle depth & 8.6 & 12.2 & 10.5 & 0.9 \\
\hline Head length & 31.5 & 37.9 & 34.2 & 1.3 \\
\hline Cleithral width & 20.7 & 25.3 & 22.7 & 1.2 \\
\hline Base of dorsal fin length & 10.2 & 13.9 & 12.1 & 0.7 \\
\hline Dorsal-fin unbranched ray length & 23.0 & 27.3 & 25.2 & 1.1 \\
\hline Pectoral-fin unbranched ray length & 24.2 & 31.9 & 28.5 & 1.8 \\
\hline Pelvic-fin unbranched ray length & 16.1 & 22.2 & 18.7 & 1.8 \\
\hline Females & 16.1 & 18.6 & 17.2 & 0.8 \\
\hline Males & 18.6 & 22.2 & 20.2 & 1.1 \\
\hline Dorsal to anal fin length & 20.8 & 25.4 & 23.1 & 0.9 \\
\hline Snout-opercle length & 23.5 & 29.0 & 26.1 & 1.3 \\
\hline \multirow[t]{2}{*}{ Body depth } & 14.7 & 19.9 & 17.3 & 1.2 \\
\hline & \multicolumn{3}{|c|}{ Percents of head length } & \\
\hline Head width & 58.5 & 68.1 & 63.7 & 2.5 \\
\hline Head depth & 39.4 & 50.7 & 45.4 & 2.8 \\
\hline Snout length & 47.4 & 54.0 & 50.7 & 1.7 \\
\hline Orbital diameter & 13.3 & 18.3 & 15.8 & 1.1 \\
\hline Interorbital length & 35.5 & 44.3 & 40.2 & 2.3 \\
\hline Maxillary barbel length & 2.2 & 8.2 & 5.9 & 1.3 \\
\hline Prenasal length & 26.2 & 34.4 & 30.4 & 1.8 \\
\hline Internasal length & 6.8 & 14.7 & 11.2 & 1.7 \\
\hline Nasal chamber width & 8.6 & 17.1 & 12.4 & 2.3 \\
\hline Females & 8.6 & 12.3 & 10.5 & 0.9 \\
\hline Males & 12.5 & 17.1 & 14.5 & 1.4 \\
\hline Nasal chamber length & 10.2 & 21.7 & 15.7 & 2.7 \\
\hline Females & 10.2 & 15.6 & 13.5 & 1.4 \\
\hline Males & 15.7 & 21.7 & 17.9 & 1.6 \\
\hline Suborbital depth & 15.2 & 22.0 & 18.5 & 1.5 \\
\hline
\end{tabular}


Table 7. Frequency distribution of meristic data for Hisonotus notatus non-types ( $\mathrm{n}=42)$. Plates (in both sides), procurrent rays, and vertebrae were counted only in c\&s specimens.

\begin{tabular}{|c|c|c|c|}
\hline Character & Frequency distribution & Range & Mode \\
\hline Dorsal plates & $22(2), 23(6)$ & $22-23$ & 23 \\
\hline Mid-dorsal plates & $4(1), 5(1), 6(1), 7(1), 9(1), 10(2), 13(1)$ & $4-13$ & 10 \\
\hline Total median plates & $21(1), 22(1), 23(1), 24(4), 28(1)$ & $21-28$ & 24 \\
\hline unperforated near caudal- peduncle end & $1(4), 2(2), 6(1), 8(1)$ & $1-8$ & 1 \\
\hline Mid-ventral plates & $18(3), 19(3), 21(2)$ & $18-21$ & $18 / 19$ \\
\hline Ventral plates & $16(1), 18(5), 19(2)$ & $16-19$ & 18 \\
\hline Lateral abdominal plates & $2(6), 3(7), 4(14), 5(12)$ & $2-5$ & 4 \\
\hline Premaxillary teeth & $15(1), 16(2), 17(2), 20(6), 21(5), 22(2), 23(6), 24(3), 26(4), 27(3), 28(3), 29(2)$ & $15-29$ & $20 / 23$ \\
\hline Dentary teeth & 14(1), 15(4), 16(3), 17(3), 18(2), 19(5), 20(4), 21(3), 22(5), 23(1), 24(1), 25(2), 26(2), 27(3) & $14-27$ & $19 / 22$ \\
\hline Dorsal-fin branched rays & $7(39)$ & - & 7 \\
\hline Pectoral-fin branched rays & $5(1), 6(38)$ & $5-6$ & 6 \\
\hline Pelvic-fin unbranched rays & $5(39)$ & - & 5 \\
\hline Anal-fin unbranched rays & $5(39)$ & - & 5 \\
\hline Caudal-fin unbranched rays & $13(1), 14(38)$ & $13-14$ & 14 \\
\hline Dorsal procurrent rays & $3(1), 4(3)$ & $3-4$ & 4 \\
\hline Ventral procurrent rays & $3(2), 4(1), 5(1)$ & $3-5$ & 3 \\
\hline Vertebrae & $28(4)$ & - & 28 \\
\hline
\end{tabular}

Anterior margin of snout rounded in dorsal view; tip of snout with single large rostral plate, its posterior margin with $U$-or $V$-shaped concavity; well-developed odontodes completely covering ventral and dorsal portions of rostral plate, postrostral plate 1, and lateroventral margin of head (Figs. 3a, c). Remaining odontodes of head and body small, randomly distributed, not forming conspicuous rows, crests or tufts. Eye small, dorsolaterally placed, not visible in ventral view. Iris operculum present. Compound pterotic fenestrae variable in size, small on laterodorsal and large on lateroventral portions; posterior extension of compound pterotic medium-sized and rounded, not surpassing rib of sixth vertebra; infraorbital canal entering infraorbital series via sphenotic. Parieto-supraoccipital not forming part of dorsal wall of swimbladder capsule.

Body entirely covered by dermal plates, except on ventral part of head, region overlying opening of swimbladder capsule, pelvic-fin origin, and urogenital pore. Abdomen completely covered by large plates; anterior plates arranged in three longitudinal rows, lateral row with 2-5(4) plates; posterior plates, between pelvic fins, randomly distributed.

Lips oval, papillose; lower lip fringy, larger than upper, falling short of pectoral girdle; papillae gradually smaller towards lip edge. Maxillary barbel reduced, free from oral disk. Teeth slender and bifid; median cusp larger and rounded, lateral smaller and pointed. Premaxillary and dentary accessory teeth absent, even in smallest examined specimen (12.2 mm SL).

Dorsal fin originating approximately at vertical through end of pelvic-fin base; tip of adpressed rays surpassing vertical line at end of anal-fin base. Spinelet small, ovoid, inserted in notch in nuchal plate; locking mechanism non-functional. Nuchal plate exposed area rectangular to pentagonal. Anterior portion of compound supraneural first dorsal-fin proximal radial contacting neural spine of seventh vertebra. Pectoral fin originating immediately behind opercular opening; tip of adpressed rays almost reaching vertical through urogenital opening; well-developed odontodes on unbranched ray, gradually enlarged toward tip. Cleithrum and coracoid almost totally exposed, with many odontodes, except for arrector fossa region covered by skin only. Arrector fossa almost completely enclosed by ventral lamina of coracoid and cleithrum, opening restricted to small anterior area near midline. Pectoral axillary slit present in juveniles and adults, large, about 1.5-2 times in orbital diameter, at angle of $45^{\circ}$ with body axis. Pelvic-fin unbranched ray shorter than branched ones. Anal-fin first proximal radial contacting haemal spine of 13th vertebra. Caudal fin concave, lower lobe slightly longer than upper. Adipose fin and azygous plates absent.

Five lateral series of plates (Fig. 3a). Dorsal series complete from posterior edge of supraoccipital to caudalpeduncle end. Mid-dorsal series short, from posterior edge of compound pterotic to near vertical through middle of dorsal-fin base; occasionally longer, with many intermediate plates lacking. Median series from compound pterotic to caudal-fin base; sometimes 1-3 plates lacking; 1-11 non-perforated plates in middle portion of series, near vertical through dorsal-fin base, and 1-8 non-perforated plates at end of series; first plate, sometimes also second, restricted to sensorial canal, occasionally fused to compound pterotic. Mid-ventral series long, from lateral process of cleithrum to vertical through tip of adpressed anal fin. Ventral series from near middle or end of pelvicfin length to caudal-peduncle end. 
Color in alcohol. Dorsal profile medium brown; dorsal area of head dark brown from tip of snout to median portion of supraoccipital. Three dorsal inconspicuous saddles: first at dorsal-fin base; second at end of dorsal-fin length; third at end of caudal peduncle. Clear stripe extending from tip of snout to near vertical through distal tip of opercle, passing by dorsal margin of postrostral plates 1 and 2 , external edge of nostril, limits between prefrontal and infraorbitals 2 and 3, and dorsal margin of orbit. Lateral profile of body homogeneously medium brown, except for yellowish lateroventral portion of head and lateral process of cleithrum, sometimes with spots forming vermiculated pattern. Ventral portion of body yellowish.

Membranes of dorsal, anal, pectoral, and pelvic fins hyaline, pigmented areas of rays arranged in interspersed bars forming transversal bands. Caudal fin densely pigmented, except for slender unpigmented edge and hyaline areas in both lobes: superior lobe with oblique blotch from posteromedial portion of unbranched ray to distal portion of median rays, and other at superior tip of lobe, these two areas separated by dark inclined line; inferior lobe with small posteromedial area restricted to unbranched ray and last branched ray, and another at inferior tip of lobe.

Sexual dimorphism. Males commonly smaller and with dorsal profile more depressed than females (Fig. 4). Males have conspicuous urogenital papilla immediately posterior to anus present, expanded flap of skin on dorsal surface of the first pelvic-fin ray present, and tip of adpressed pelvic fin generally reaching anal-fin origin. Nasal chamber of males enlarged, its width $12.5-17.1 \%$ in HL (vs. 8.6-12.3\% in females), and its length $15.7-21.7 \%$ in HL (vs. $10.2-15.6 \%$ in females).

Distribution. Restricted to the rio São João drainage and other small coastal drainages running to the Baía de Guanabara and to the Baía de Sepetiba in the Rio de Janeiro State (Fig. 5).

Conservation status. Despite of the relatively small extent of occurrence (approximately 2,661 km²), a threat criterion according to IUCN, Hisonotus notatus is a common species, being well-represented in fish collections and usually abundant in the sampling sites. In addition, no current risk was recognized that may endanger the species. Thus, according to the International Union for Conservation of Nature (IUCN) categories and criteria (IUCN Standards and Petitions Subcommittee, 2014), Hisonotus notatus can be classified as Least Concern (LC).

Remarks. The original description of Hisonotus notatus was based on specimens of two different lots: MCZ 8177, with a single specimen from the rio Paraíba do Sul drainage in Juiz de Fora, Minas Gerais State; and MCZ 7764, from Santa Cruz, Rio de Janeiro State. The latter lot originally had 95 specimens and today has 79 specimens, since
12 were exchanged: six to the fish collection of ANSP (ANSP 166924) and six to the MNRJ (MNRJ 28882). The remaining four specimens were not found during the last counting by the staff of MCZ in the year of 2012, according to information on online data base of the fish collection of MCZ. The specimens of lots MCZ 7766 and MCZ 7768 are erroneously referred as cotypes of $H$. notatus in the catalog book of MCZ, since they are not mentioned by Eigenmann \& Eigenmann (1889) in the original description. Our observations revealed that the type series of Hisonotus notatus is mixed, and the specimens from the two original lots belong to two different species, one of them ( $\mathrm{MCZ}$ 8177) described herein as new. Based on that, we restricted $H$. notatus to the specimens originally from MCZ 7764 , and in order to clarify the taxonomic status of this nominal species, following the article 74 of the International Code of Zoological Nomenclature (ICZN, 1999), we designate here a specimen as a lectotype. Although the material has been sampled in 1865, the specimens are all well preserved, and we chose as the lectotype the specimen in best condition from the lot MNRJ 28882, representing the most abundant original sampling. Thus, $H$. notatus is herein restricted to the rio São João drainage and to other small coastal drainages running to the Baía de Sepetiba and to the Baía de Guanabara, such as rio Grande drainage and rio Macacu drainage, while $H$. thayeri occurs in coastal basins of rio Paraíba do Sul, Lagoa Feia, rio Macaé, rio Itabapoana, rio Itapemirim, rio Novo, rio Benevente, and rio Doce.

The data from the type locality of $H$. notatus are controversial. In the MCZ record book, the only information is Santa Cruz for the locality, and Dom Pedro for the collector. Later, in a paper that provides details of the collecting sites of the Thayer Expedition, Higuchi (1996) presented the following information for this sample point (field number Thayer 114): Rio de Janeiro, Santa Cruz, rio Grande (arroio Fundo), in the urban area of Rio de Janeiro Municipality, Santa Cruz farm - Emperor Pedro II's farm, ca. 22 $56^{\circ}$ 'S $43^{\circ} 12^{\prime}$ W, Apr 1865, D. Pedro II, D. Bourget. Curiously, Higuchi (1996) gave the same geographical coordinates for point Thayer 156, for which the original label reads "rio Quenda" or "rio Quendu" in handwritting. He proposed the handwritten locality as an error, and pointed that the collection probably was made near or at Emperor Pedro II's Fazenda Santa Cruz, as well as Thayer 114. However, the old Emperor Pedro II's farm, in Santa Cruz, is about $50 \mathrm{~km}$ straight west to the geographical coordinate suggested by Higuchi (1996), today an urban area. At the farm there is no reference to rio Grande, being this area drained by the rio Guandu basin, probably referred by collectors in the original label as "rio Quendu". Based on this, we propose $22^{\circ} 54^{\prime} 40^{\prime \prime} \mathrm{S} 43^{\circ} 41^{\prime} 7^{\prime \prime} \mathrm{W}$ as the geographical coordinate representing Thayer 114 and 156 collection points, and consequently the type locality for $H$. notatus. This location is at the old Emperor Pedro II's farm, more specifically at the farm headquarters, today a building used by the Brazilian Army. 
Material examined. Types. MNRJ 42969, lectotype, PRESENT DESIGNATION, $31.3 \mathrm{~mm}$ SL, Brazil, Rio de Janeiro State, Santa Cruz, rio Guandu, Santa Cruz farm - Emperor Pedro II's farm, 22 54 '40"S 4341' 7'”, Apr 1865, D. Pedro II \& D. Bourget. MCZ 7764, paralectotypes, 79 (17, 24.4-32.2 mm SL); MNRJ 28882, 5 (2, 28.8-32.2 mm SL), collected with lectotype. Non-types. All from Brazil, Rio de Janeiro State. Rio Cação drainage: MZUSP 10315, 22, 22.4-31.0 mm SL, Itaguaí, córrego of Lagoa Nova, km 7 on the road Itaguaí-Raiz da Serra. MZUSP 10316, 28, 22.6-34.2 $\mathrm{mm}$ SL, Itaguaí, ribeirão of Ponte do Teixeira, $\mathrm{km} 5$ on the road Itaguaí-Raiz da Serra. Rio Grande drainage: MZUSP 23767, 20, 23.6-34.8 mm SL, Rio de Janeiro, Jardim Palmares, km 52 on the road Rio-Santa Cruz. Rio Macacu drainage: MNRJ 13737, 31, 14.2-26.55 mm SL, Cachoeiras de Macacu, affluent to rio Soarinho, near Papucaia. MNRJ 15741, 124 (4 c\&s), 16.1-38.3 mm SL (28.4$38.3 \mathrm{~mm}$ SL), Cachoeiras de Macacu, rio Macacu. MNRJ 18033, 2, 29.2-30.8 mm SL, Guapimirim, rio Paraíso. MNRJ 19386, 15, 19.3-36.1 mm SL, Cachoeiras de Macacu, rio Guapiaçu. MNRJ 20286, 1, 32.9 mm SL, Guapimirim, rio Paraíso. MNRJ 20346, 51, 16.7-39.0 mm SL, rio Macacu. Rio São João drainage: DZSJRP 13836, 1, $34.9 \mathrm{~mm}$ SL, Silva Jardim, affluent to rio São João. DZSJRP 13852, 46 (3 c\&s), 14.3-39.4 mm SL (27.6-39.4 mm SL), Silva Jardim, affluent to rio São João. DZSJRP 13874, 22, 13.8 $43.5 \mathrm{~mm}$ SL (31.6-43.5 mm SL), Silva Jardim, affluent to rio São João. DZSJRP 13889, 23 (1 c\&s), 20.4-45.2 mm SL (35.2-45.2 mm SL), Silva Jardim, affluent to rio São João. MBML 2089, 10 , 24.3-40.0 mm SL, Silva Jardim, córrego Bananeiras. MBML 2104, 4, 29.1-30.8 mm SL, Silva Jardim, rio São João. MNRJ 13552, 30 (2 c\&s), 12.2-31.5 mm SL, Silva Jardim, rio São João. MNRJ 19253, 12, 30.3-36.1 mm SL, Silva Jardim, rio Pirineus/Crubixais. MNRJ 19262, 5, 21.0-34.7 mm SL, Silva Jardim, córrego Água Fria affluent to rio Pirineus. MNRJ 19267, 5, 23.8-31.1 mm SL, Silva Jardim, rio do Ouro. MNRJ 19277, 10, 21.8-26.1 mm SL, Rio Bonito, rio dos Índios. MNRJ 37448, 6, 14.0-41.40 mm SL, Silva Jardim, rio Aldeia Velha. MNRJ 37500, 30, 21.8-44.8 mm SL, Casimiro de Abreu, córrego Aldeia Velha. MNRJ 37826, 5, 22.8$31.0 \mathrm{~mm}$ SL, Casimiro de Abreu, córrego Ipiabas. MNRJ 37855, 1, 34.2 mm SL, Silva Jardim, rio Iguape. MNRJ 38097, 2, 31.2-33.3 mm SL, Silva Jardim, rio São João. MNRJ 38103, 3, 29.3-36.1 mm SL, Casimiro de Abreu, rio Lontras. MNRJ 38114, 24, Rio Bonito, rio Bacaxa. MNRJ 38147, 10 of 42 (1 c\&s), 28.1-39.9 mm SL, Silva Jardim rio Maratua. Other drainages: MNRJ 17703, 44, 20.6-34.0 mm SL, Magé, rio Suruí. MNRJ 39003, 7, 27.3-3.8 mm SL (27.3-35.8 mm SL), Piabetá, affluent to rio Inhomirim.

Types not examined. ANSP 166924, 6, collected with lectotype.

\section{Discussion}

In addition to Hisonotus notatus and $H$. thayeri, the coastal rivers of Rio de Janeiro State shelter many species of the Hypoptopomatinae: Otocinclus affinis Steindachner, 1877, Otothyris lophophanes (Eigenmann \& Eigenmann, 1889), Parotocinclus bidentatus Gauger \& Buckup, 2005, P. muriaensis Gauger \& Buckup, 2005, P. maculicauda (Steindachner, 1877), Pseudotothyris janeirensis Britski
\& Garavello, 1984, and Schizolecis guntheri MirandaRibeiro, 1918. Some of them inhabit simultaneously the rio Paraíba do Sul basin and other small coastal drainages, while others are restricted to small coastal drainages (such as Pseudotothyris janeirensis) or to the rio Paraíba do Sul (such as Parotocinclus bidentatus and P. muriaensis). This geographical separation pattern is evident for $H$. notatus and $H$. thayeri, with the former species present only in the rio São João basin and other small rivers that run directly to the Baía de Guanabara or to Baía de Sepetiba, while H. thayeri occurs in the drainages of the rio Paraíba do Sul, Lagoa Feia, rio Macaé, and coastal rivers of Espírito Santo State, from rio Itabapoana to rio Doce basin.

The northern region of Rio de Janeiro State, known as Baixada dos Goytacazes, is featured by Precambrian mountain chains forming a semicircle, which ends exactly between the mouths of the rio São João and rio Macaé (Primo et al., 2002), matching the northernmost occurrence for Hisonotus notatus. Thus, despite of the geographical proximity between rio São João inhabited by $H$. notatus and rio Macaé, where $H$. thayeri is found, these two basins harbor different faunas, and the rio Macaé, as well as the lake drainages of Baixada dos Goytacazes, share many species with the rio Paraíba do Sul, to the north, corroborating the presence of ancient communications between these drainages, as already pointed out by other authors (e.g. Bizerril, 1999).

According to the phylogenetic analysis, $H$. notatus and $H$. thayeri are sister-taxa based on the possession of a central neural spine of eighth vertebra reduced (char. 51, state 0 ). This condition is present in most of the species of Hisonotus (except for $H$. armatus, $H$. carreiro, $H$. francirochai, $H$. iota, $H$. ringueleti, and $H$. vireo , and for $H$. alberti and $H$. pachysarkos which were not examined), and probably it would not be optimized as a synapomorphy to $H$. notatus $+H$. thayeri in a more inclusive analysis.

The fewer number of plates in the mid-dorsal series in $H$. notatus is the main distinctive feature between this species and $H$. thayeri. During the ontogenetic development, the mid-dorsal series of plates together with the mid-ventral, are the last to ossify. Also, in opposition to the other lateral series, this ossification occurs from anterior to posterior along the body. Examining ontogenetic series of Otothyris Myers, 1927, Rosa et al. (2014) suggested the reduction of mid-dorsal series as a derived feature, referring to the conservation of a juvenile feature in adults, probably related to the interruption of the development of this series of plates. The most basal members of the Hypoptopomatinae share with most of the Neoplecostominae the mid-dorsal series of plates not reaching the end of the caudal peduncle, but surpassing the vertical of adpressed dorsal fin (char. 69 , state 1 in Martins et al., 2014), a condition derived from a complete mid-dorsal series. According to Martins et al. (2014), reduction of mid-dorsal series can be observed in different degrees among the hypoptopomatines, acquired independently many times within the subfamily. 
A mid-dorsal series surpassing the length of folded dorsal fin, as present in $H$. thayeri and considered plesiomorphic for the Hypoptopomatinae, is rare among Hisonotus species and can be also observed for example in $H$. bocaiuva Roxo, Silva, Oliveira \& Zawadzki, 2013, H. depressicauda (Ribeiro, 1918), H. francirochai (von Ihering, 1928), $H$. nigricauda (Boulenger, 1891), and $H$. ringueleti Aquino, Schaefer \& Miquelarena, 2001. On the other hand, the most common condition among the Hisonotus species is a greater reduction of the number of plates in the mid-dorsal series. However, many degrees of this condition are observed in the genus: in H. charrua, $H$. iota, H. leucophrys, and $H$. notatus, the mid-dorsal series of plates reaches no further than the vertical through end of dorsal-fin length (char. 69, state 2 in Martins et al., 2014); in $H$. notatus the series can also be truncated in the middle (char. 69, state 4 in Martins et al., 2014). A shorter mid-dorsal series with six or less plates often not even reaching the vertical through dorsal-fin origin (char. 69, state 3 in Martins et al., 2014) is found in $H$. aky (Azpelicueta, Casciotta, Almirón \& Koerber, 2004), H. armatus Carvalho, Lehmann, Pereira \& Reis, 2008, $H$. carreiro Carvalho \& Reis, 2011, H. chromodontus Britski \& Garavello, 2007, H. heterogaster Carvalho \& Reis, 2011, H. laevior Cope, 1894, H. leucofrenatus (Ribeiro, 1908), H. megaloplax Carvalho \& Reis, 2009, H. montanus Carvalho \& Reis, 2009, H. taimensis (Buckup, 1981), and H. vireo Carvalho \& Reis, 2011. The detailed evolution of this feature among species of Hisonotus is beyond the scope of this paper and was part of the doctoral study of one of the authors (FOM).

\section{Acknowledgements}

We are grateful to Scott Schaefer (AMNH), Luisa Sarmento-Soares (MBML), Roberto Reis and Carlos Lucena (MCP), George Lauder and Karsten Hartel (MCZ), Paulo Buckup and Marcelo Britto (MNRJ), and José Lima Figueiredo and Osvaldo Oyakawa (MZUSP) for providing specimens deposited in their respective institutions and make this study possible. The authors were supported by fellowships from Fundação de Amparo à Pesquisa do Estado de São Paulo (FAPESP, processes \# 2011/21728-7 to FOM and 2012/23224-9 to FL), and Conselho Nacional de Desenvolvimento Científico e Tecnológico (CNPq, process \# 306.566/2014-1 to FL).

\section{References}

Arratia, G. \& M. Gayet. 1995. Sensory canals and related bones of tertiary siluriform crania from Bolivia and North America and comparison with recent forms. Journal of Vertebrate Paleontology, 15: 482-505.

Bachman, S., J. Moat, A. W. Hill, J. de la Torre \& B. Scott. 2011. Supporting Red List threat assessments with GeoCAT: geospatial conservation assessment tool. Zookeys, 150: 117-126.
Bizerril, C. R. S. F. 1999. A Ictiofauna da bacia do rio Paraíba do Sul. Biodiversidade e padrões biogeográficos. Brazilian Archives of Biology and Technology, 42: 233-250.

Eigenmann, C. H. \& R. S. Eigenmann. 1889. Preliminary notes on South American Nematognathi II. Proceedings of the California Academy of Sciences, 2d Ser., 2: 28-56.

Eigenmann, C. H. \& R. S. Eigenmann. 1890. A revision of the South American Nematognathi or cat-fishes. Occasional Papers of the California Academy of Sciences, 1: 1-508.

Eschmeyer, W. N. (Ed.) 1998. Catalog of fishes. San Francisco, California Academy of Sciences, 3 v., ill. (2905p). (Special publication no. 1 of the Center for Biodiversity Research and Information).

Eschmeyer, W. N., R. Fricke \& R. van der Laan (Eds.). 2016. Catalog of fishes: genera, species, references. Available from: http://researcharchive.calacademy.org/research/ichthyology/ catalog/fishcatmain.asp (22 February 2016).

Ferraris, C. J., Jr. 2007. Checklist of catfishes, recent and fossil (Osteichthyes: Siluriformes), and catalogue of siluriform primary types. Zootaxa, 1418: 1-628.

Fowler, H. W. 1954. Os peixes de água doce do Brasil (v. 2). Arquivos de Zoologia do Estado de São Paulo, 9: 1-400.

Gauger, M. F. W. \& P. A. Buckup. 2005. Two new species of Hypoptopomatinae from the rio Paraíba do Sul basin, with comments on the monophyly of Parotocinclus and the Otothyrini (Siluriformes: Loricariidae). Neotropical Ichthyology, 3: 509-518.

Higuchi, H. 1996. An updated list of ichthyological collecting stations of the Thayer Expedition to Brazil (1865-1866). Available from: http://www.mcz.harvard.edu/Departments/ Ichthyology/docs/Higuchi_1996_Thayer_Formated_prelim. pdf. (12 April 2016).

International Commission on Zoological Nomenclature (ICZN). 1999. Code of Zoological Nomenclature adopted by the International Union of Biological Sciences. 4th ed. London, International Trust for Zoological Nomenclature, Natural History Museum, 106p.

IUCN. Standards and Petitions Subcommittee. 2014. Guidelines for using the IUCN Red List Categories and Criteria. Version 11. Prepared by the Standards and Petitions Subcommittee. Cambrigde, International Union for Conservation of Nature (IUCN), 87p. Available from: http://www.iucnredlist.org/ documents/RedListGuidelines.pdf. (26 June 2015).

Martins, F. O., H. A. Britski \& F. Langeani. 2014. Systematics of Pseudotothyris (Loricariidae: Hypoptopomatinae). Zoological Journal of the Linnean Society, 170: 822-874.

Martins, F. O. \& F. Langeani. 2011. Microlepidogaster dimorpha, a new species of Hypoptopomatinae (Siluriformes: Loricariidae) from the upper rio Paraná system. Neotropical Ichthyology, 9: 79-86.

Miranda-Ribeiro, A. 1911. Fauna Brasiliense. Peixes. Tomo IV (A) [Eleutherobranchios Aspirophoros]. Archivos do Museu Nacional do Rio de Janeiro, 16: 1-504.

Primo, P. B. S., C. R. S. F. Bizerril \& A. Soffiati. 2002. Lagoas do Norte Fluminense - perfil ambiental. Rio de Janeiro, Secretária de Estado de Meio Ambiente e Desenvolvimento Sustentável, 148p. 
Regan, C. T. 1904. A monograph of the fishes of the family Loricariidae. Transactions of the Zoological Society of London, 17, pt. 3: 191-350.

Reis, R. E. \& T. P. Carvalho. 2007. Família Loricariidae: Hypoptopomatinae. Pp. 82-87. In: Buckup, P. A., N. A. Menezes \& M. S. Ghazzi (Eds.). Catálogo das espécies de peixes de água doce do Brasil. Rio de Janeiro, Museu Nacional. (Série Livros, 23).

Rosa, A. C., F. O. Martins \& F. Langeani. 2014. Miniaturization in Otothyris Myers, 1927 (Loricariidae: Hypoptopomatinae). Neotropical Ichthyology, 12: 53-60.

Schaefer, S. A. 1991. Phylogenetic analysis of the loricariid subfamily Hypoptopomatinae (Pisces: Siluroidei: Loricariidae), with comments on generic diagnoses and geographic distribution. Zoological Journal of the Linnean Society, 102: 1-41.

Schaefer, S. A. 1997. The Neotropical cascudinhos: systematics and biogeography of the Otocinclus catfishes (Siluriformes: Loricariidae). Proceedings of the Academy of Natural Sciences of Philadelphia, 148: 1-120.

Schaefer, S. A. 1998. Conflict and resolution: impact of new taxa on phylogenetic studies of the Neotropical cascudinhos (Siluroidei: Loricariidae). Pp. 375-400. In: Malabarba, L. R., R. E. Reis, R. P. Vari, Z. M. S. Lucena \& C. A. S. Lucena (Eds.). Phylogeny and classification of Neotropical fishes. Porto Alegre, Edipucrs.
Schaefer, S. A. 2003. Subfamily Hypoptopomatinae (Armored catfishes). Pp. 321-329. In: Reis, R. E, S. O. Kullander \& C. J. Ferraris Jr. (Orgs.). Check list of the freshwater fishes of South and Central America. Porto Alegre, Edipucrs.

Steindachner, F. 1877. Die Süsswasserfische des südöstlichen Brasilien. (IV). Sitzungsberichte der Kaiserlichen Akademie der Wissenschaften in Wiena Mathematisch Naturwissenschaftliche Klasse Abteilung I, 75: 217-230.

Taylor, W. R. \& G. C. Van Dyke. 1985. Revised procedures for staining and clearing small fishes and other vertebrates for bone and cartilage study. Cybium, 9: 107-119.
Submitted July 10, 2015 Accepted March 26, 2016 by George Mattox 